\title{
First description of Tanyderidae (Diptera) larvae from South America
}

\section{Первое описание кичинок Tanyderidae (Diptera) из Южной Америки}

\author{
Elena D. Lukashevich \& Dmitry E. Shcherbakov \\ Е.А. Аукашевич, А.Е. Щербаков
}

Borissiak Paleontological Institute, Russian Academy of Sciences, Moscow, Russia; elukashevich@hotmail.com, dshh@narod.ru Палеонтологический институт им. А.А. Борисяка РАН, Москва, Россия.

KEY WORDS: morphology, spiracles, 1st instar, Chile, xylophagy, SEM, COI gene, living fossils.

КЛЮЧЕВЫЕ СЛОВА: морфология, дыхальца, I возраст, Чили, ксилофаг, СЭМ, ген СОІ, живые ископаемые.

ABSTRACT. Larvae of Tanyderidae were collected in logs submerged in streams among Nothofagus forests of Chile (Araucania and Los Lagos). They dwell under the bark, sometimes in self-dug chambers, and have their guts filled with crushed wood fragments. The larvae were identified as ?Tanyderus pictus Philippi, 1865 based on their COI gene sequences being strongly different from those of adult Araucoderus gloriosus (Alexander, 1920), the only other tanyderid species known from the region. Previously published and new records of South American Tanyderidae are listed. The morphology of all four larval instars of ?T. pictus is described and illustrated. Rudimentary spiracles on the metathorax and abdominal segments I-VII of all but the 1 st instar are recorded for the first time for Tanyderidae. The 1st-instar larva, not previously studied in this family, differs from the older instars remarkably. In its larval characters ?Tanyderus is similar to but distinct from Mischoderus, Radinoderus and Eutanyderus. A key to tanyderid genera based on larvae is provided. The generation time was estimated as two years in at least one of the localities studied. Photographs of live larvae of ?Tanyderus and adults of Araucoderus are included.

РЕЗЮМЕ. Личинки танидерид собраны в Чили (Араукания и Озерный Край) в речках и ручьях среди лесов с доминированием южных буков. Они развиваются под корой затопленных мёртвых стволов, иногда выгрызая короткие ходы, и их кишечник содержит фрагменты древесины. Личинки отнесены предположительно к Tanyderus pictus Philippi, 1865, поскольку по гену COI они сильно отличаются от имаго Araucoderus gloriosus (Alexander, 1920), второго вида танидерид, известного из данных областей. Перечислены ранее опубликованные и новые находки южноамериканских танидерид. Описано строение личи- нок всех четырёх возрастов ?T. pictus. Впервые для танидерид отмечены рудиментарные дыхальца на заднегруди и I-VII брюшных сегментах у личинок всех возрастов, кроме первого. Личинка первого возраста, ранее для этого семейства не описанная, сильно отличается от последующих возрастов. По личиночным признакам ?Tanyderus близок к Mischoderus, Radinoderus и Eutanyderus, но хорошо от них отличается. Составлен ключ для определения личинок танидерид до рода. Жизненный цикл, вероятно, двухлетний (по крайней мере, в одной из точек сбора). Приведены фотографии живых личинок ?Tanyderus и имаго Araucoderus.

\section{Introduction}

The family Tanyderidae, or primitive crane flies, is an ancient and archaic nematoceran group, known since the Early Jurassic [Ansorge, 1994]. Some Jurassic tanyderids, both adults and larvae, have even been referred to an extant genus, Protanyderus Handlirsch, 1909 [Kalugina, 1992; Lukashevich \& Krzemiński, 2009]. Interestingly, the first described member of this family was a fossil (Macrochile spectrum Loew, 1850 from Eocene Baltic amber), which justifies viewing the later discovered extant species as true "living fossils." A close relationship of Tanyderidae to Psychodidae is supported by the existence of an intermediate group, extant Bruchomyiinae (formerly placed in Tanyderidae, now in Psychodidae [Alexander, 1928]) and extreme similarity of some fossil tanyderids to psychodids [Poinar \& Brown, 2006; Krzemiński et al., 2013] as well as molecular data [Wiegmann et al., 2011; Curler \& Moulton, 2012]. Tanyderids have a bipolar distribution with higher diversity in the South- 
ern Hemisphere, and were even more widespread in the Mesozoic [Krzemiński \& Judd, 1997]. The family includes 37 extant species in 10 genera. Only three monotypic genera are known in South America, all in the temperate zone and all described from Chile: Tanyderus Philippi, 1865, Neoderus Alexander, 1927 and Araucoderus Alexander, 1929.

Knowledge of tanyderid larvae is sparse. To date, they have been described for no more than nine extant species in six genera: Protoplasa fitchii Osten-Sacken, 1860 from the Nearctic [Alexander, 1930; Crampton, 1930]; several species of Protanyderus, probably $P$. vipio (Osten-Sacken, 1877) and P. margarita Alexander, 1921 from the Nearctic [Knight, 1963; Rose, 1963; Exner \& Craig, 1976], and P. esakii Alexander, 1932 and P. stackelbergi Savchenko, 1971 from the Palaearctic [Krzemiński \& Judd, 1997; Podeniene \& Gelhaus, 2013]; Peringueyomyina barnardi Alexander, 1921 from South Africa [Wood, 1952]; Eutanyderus wilsoni Alexander, 1928, Mischoderus sp. and Radinoderus sp. from Australasia [Colless \& McAlpine, 1970; Anthon, 1988; Judd, 2004]. Only the larvae of $P$. fitchii and $E$. wilsoni have been confidently associated with adults by rearing. The larvae of Mischoderus sp. [Anthon, 1988] have also been reared to adults [Pilgrim, 1990]. The other larvae have been identified based on their co-occurrence with certain adults or falling within their range of distribution.

In January 2014 we collected several adults and larvae of Tanyderidae in Chile. The adults, captured in the national parks Alerce Andino and Puyehue, were males of Araucoderus gloriosus (Alexander, 1920). The larvae, collected in the national parks Alerce Andino and Nahuelbuta, were not reared to adults, and due to their co-occurrence with adult males in Alerce Andino were initially identified as the same species. However, sequences of their COI gene revealed their strong difference from the Araucoderus adults, indicating that they belong to a different species. Because the only other tanyderid known from this part of Chile is Tanyderus pictus Philippi, 1865 (the type of the family, "the largest and most beautiful member of the entire group" [Alexander, 1936]), we cautiously refer to these larvae as ?Tanyderus pictus.

Known tanyderid larvae occur in two types of aquatic habitats. The larvae of Protanyderus, Araucoderus, Protoplasa Osten-Sacken, 1860, Mischoderus Handlirsch, 1909, Peringueyomyina Alexander, 1921, and New Guinean species of Radinoderus Handlirsch, 1909 occur in the hyporheic zone of sand or cobble bottom streams and rivers, and larvae of Eutanyderus Alexander, 1928 and Australian species of Radinoderus bore in surface layers of submerged rotting logs in streams [Krzemiński \& Judd, 1997; Judd, 2004]. A larva of Protanyderus stackelbergi was found in a Populus leaf pack in a stream [Podeniene \& Gelhaus, 2013]. The larvae of ?Tanyderus were found by us in submerged rotting logs. These are the first larvae of South American Tanyderidae to be described and illustrated.

\section{Material examined}

The study is based on examination of 44 ?Tanyderus pictus larvae and 7 Araucoderus gloriosus adults collected in January 2014 in the national parks Alerce Andino, Puyehue and Nahuelbuta. The larvae and 2 adults were preserved in $70 \%$ or $96 \%$ ethanol, and the other adults were preserved dry.

Larvae of ?T. pictus: Alerce Andino National Park: Lenca River, 340 masl ( $\left.41^{\circ} 30^{\prime} \mathrm{S} 72^{\circ} 37^{\prime} \mathrm{W}\right), 8.01 .2014$, D.E. Shcherbakov, E.D. Lukashevich, 22 specimens (3rd and 4th instars); Nahuelbuta National Park: Pehuenco, small creek, 1160 masl $\left(37^{\circ} 49^{\prime} \mathrm{S} 73^{\circ} 00^{\prime} \mathrm{W}\right)$, 24-25.01.2014, E.D. Lukashevich, 22 specimens (all instars).

Adults of A. gloriosus: Alerce Andino National Park: Lenca River, 340 masl ( $\left.41^{\circ} 30^{\prime} \mathrm{S} 72^{\circ} 36^{\prime} \mathrm{W}\right), 6-8.01 .2014$ D.E. Shcherbakov, 3 males. Puyehue National Park: Anticura River near Anticura Waterfall, 400 masl ( $\left.40^{\circ} 40^{\prime} \mathrm{S} 72^{\circ} 10^{\prime} \mathrm{W}\right), 14-15.01 .2014$, E.D. Lukashevich, D.E. Shcherbakov, A.F. Emeljanov, 3 males; Chanlefu River at Aguas Calientes, 470 masl $\left(40^{\circ} 44^{\prime} \mathrm{S} 72^{\circ} 18^{\prime} \mathrm{W}\right), 16.01 .2014$, D.E. Shcherbakov, 1 male.

\section{Methods}

Photographs were taken using a Leica M165C stereomicroscope with a Leica DFC425 digital camera, Zstacked using Helicon Focus 4.10 Pro and adjusted in Adobe Photoshop ${ }^{\circledR}$ CS3 10.0. Scanning electron micrographs of uncoated and gold-coated specimens were taken with a Tescan Vega microscope using backscattered electron (BSE) and secondary electron (SE) detectors. Prior to the examination, the larvae were dehydrated in graded alcohols, soaked in hexamethyldisilazane, and dried.

Measurements were taken from wet specimens using a MPS-2 stereomicroscope equipped with an ocular micrometer. The two dorsal measurements of the head capsule refer to its maximum length (omitting the labrum) and width (behind the antennae). Because the overall body length substantially overlaps between instars, only the maximum length of the 4th instar and the length of the 1st instar are reported below. Terminology is based mainly on Anthon [1988].

For DNA sequencing we selected ethanol-preserved 2 adult males of $A$. gloriosus, from the Lenca and Chanlefu River sites, and $24^{\text {th }}$-instar larvae of ?T. pictus, from the Lenca River and NP Nahuelbuta. DNA was extracted from 1 leg of each adult and 1 abdominal segment of each larva using a Wizard ${ }^{\circledR}$ SV Genomic DNA Purification System (Promega) kit according to the manufacturer protocol. In order to increase concentration, DNA was eluted from microcolumns with 2 successive aliquots of hot water. A $640-658$ bp fragments of the COI mitochondrial gene were amplified using standard Folmer's primers COI1490 (GGTCAACAAATCATAAAGATATTGG) and COH2198 (TAAACTTCAGGGTGACCAAAAAATCA) [Folmer et al., 1994] at an annealing temperature of $48^{\circ} \mathrm{C}$. The amplicons were purified, sequenced using a BigDye v3.1 (Life Technologies, USA) kit from both ends with the same primers, and the products were visualized on an ABI 3130 capillary sequencer. Lasergene v7.0 (Dna- 
Star, USA) was used for editing the chromatograms and assembling the reads, and ClustalW (www.ebi.ac.uk/ clustalw) for sequence alignment and estimation of distances.

\section{Records of South American Tanyderidae}

The published records of Tanyderus pictus are eight specimens from six localities in Chile (near Concepcion, Los Ulmos, Contulmo, Puyehue, Cayutué, and Puerto Varas) [Alexander, 1936]. These localities lie between $\sim 37^{\circ} \mathrm{S}$ and $41^{\circ} 20^{\prime} \mathrm{S}$ and do not exceed $250-300$ masl in altitude. Those specimens for which the collecting dates are known have been collected in November or March [Alexander, 1936]. Our record of the larvae from Alerce Andino, at $41^{\circ} 30^{\prime} \mathrm{S}$, slightly extends the known range of $T$. pictus to the south, while the record from Nahuelbuta, at 1160 masl, shows that the species occurs at higher altitudes than was suggested by previous records.

The published records of Araucoderus gloriosus are 2 males from Chile (Casa Pangue and Rio Aysén) and 1 female from Argentina (Neuquén, Cerro Chapelco, 1700 masl). These localities lie between $40^{\circ} 10^{\prime}$ and $45^{\circ} \mathrm{S}$; the only reported collecting time is December [Alexander, 1920, 1929, 1959]. Alexander \& Alexander [1967] reported the species from Tucumán, Argentina, probably in error, citing a previous paper published in a Tucumán-based journal [Alexander, 1952] where
A. gloriosus was listed as not yet found but possibly present in Argentina.

We collected seven males of Araucoderus gloriosus (Figs 1-2), one at a time, along the Rivers Lenca (NP Alerce Andino), Anticura and Chanlefu (both NP Puyehue, $100 \mathrm{~km}$ to the north of Alerce Andino) by sweeping riparian shrubs, mostly Fuschia magellanica, and trees, in one case some $20 \mathrm{~m}$ away from the river. Only 1 male was noticed before capture, flying on a late morning near a stream and landing onto a steep, partly shaded side of a large mossy boulder; when seated, the disruptive colour pattern of its wings and abdomen blended perfectly into the speckled background. At the Lenca River, 2 males of A. gloriosus were collected some 150 $\mathrm{m}$ and another male about $1 \mathrm{~km}$ upstream from the site where the larvae of ?T. pictus were found, suggesting that the two species sometimes co-occur in the same part of a stream, the larvae of Araucoderus reportedly living in the bottom substrate [Judd, 2004] and those of?Tanyderus in submerged rotting wood. It is possible that we encountered adults of only $A$. gloriosus because the adults of $T$. pictus emerge at a different time of year.

The only published record of Neoderus patagonicus (Alexander, 1913) is the holotype female from Latitude Cove [Alexander, 1913], San Esteban Channel, Patagonia, Chile $\left(50^{\circ} 50^{\prime} 54^{\prime \prime} \mathrm{S} 74^{\circ} 16^{\prime} 00^{\prime \prime} \mathrm{W}\right.$ according to King [1832]; mentioned as "Argentina, Patagonia, Latitude Cove" in [Alexander \& Alexander, 1967]). That site is $1000 \mathrm{~km}$ to the south from the localities where we found the larvae of ?T. pictus.
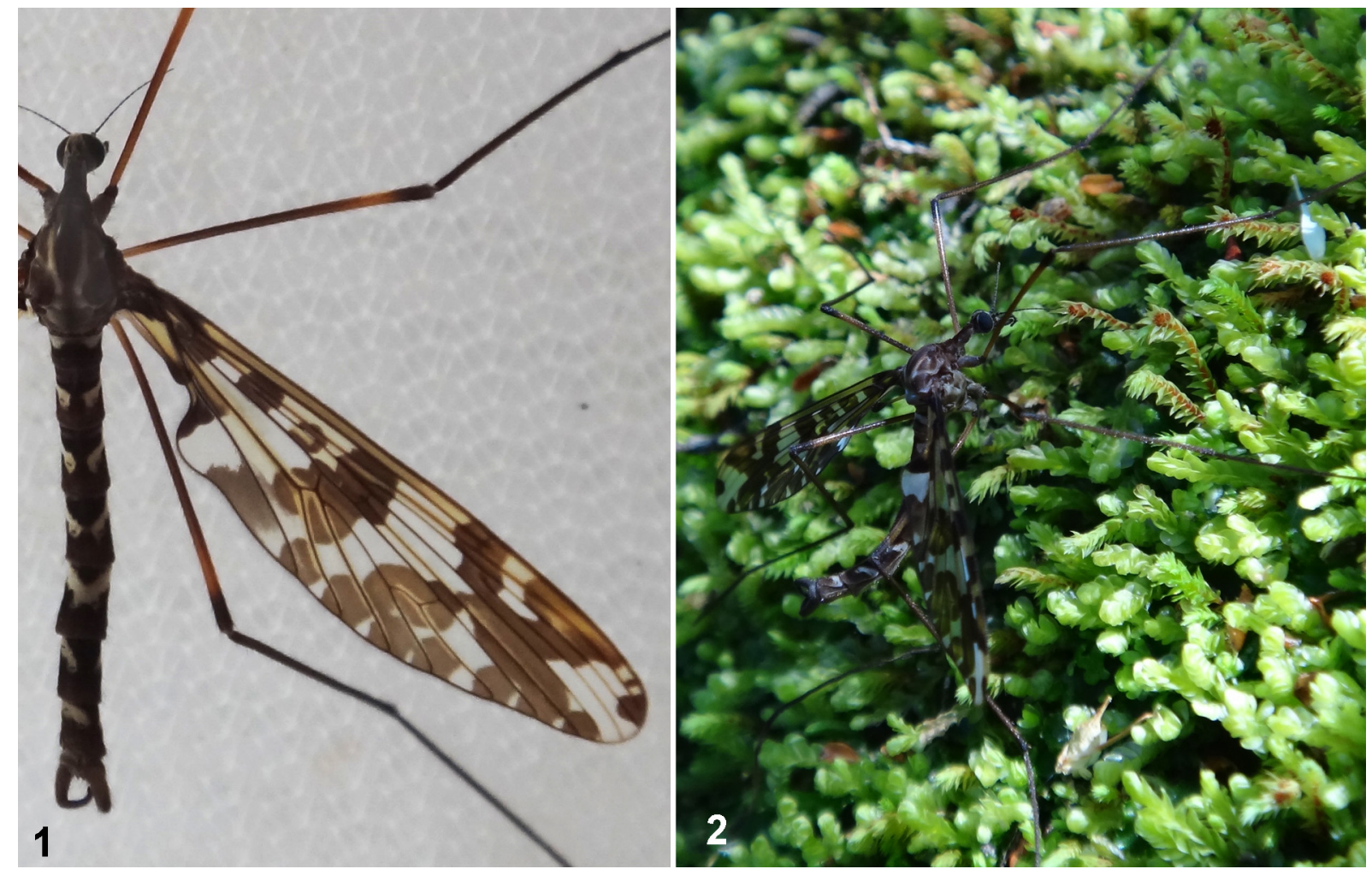

Figs 1-2. Live males of Araucoderus gloriosus: 1 - Alerce Andino; 2 - Puyehue (Anticura).

Рис. 1-2. Живые самцы Araucoderus gloriosus: 1 - Алерсе Андино; 2 - Пуйеуэ (Антикура). 
Table. COI amino acid distances (\%) for Tanyderidae and selected nematocerans. The length of the alignment used for the calculation was 199 amino acids. In the online version the distances are highlighted as follows: $<3 \%$ blue, $4-6 \%$ green, 6-8\% yellow, >10\% pink. GenBank numbers: Protoplasa fitchii gi|357018170, Brumptomyia guimaraesi gi|546605174, Pneumia borealis gi|376320230, Ptychoptera quadrifasciata gi|264688575, Dicranota sp. gi|333972978, Bittacomorpha clavipes gi|29171092, Tipula varipennis gi|392975165.

Таблица. Аминокислотные расстояния по гену COI (\%) между Tanyderidae и некоторыми другими Nematocera. Длина использованного в расчетах выравнивания 199 аминокислот. В онлайн-версии расстояния выделены цветом: <3\% голубым, 4-6\% зеленым, 6-8\% желтым, >10\% розовым. Номера ГенБанка: Protoplasa fitchii gi|357018170, Brumptomyia guimaraesi gi|546605174, Pneumia borealis gi|376320230, Ptychoptera quadrifasciata gi|264688575, Dicranota sp. gi|333972978, Bittacomorpha clavipes gi|29171092, Tipula varipennis gi|392975165.

\begin{tabular}{|c|c|c|c|c|c|c|c|c|}
\hline & 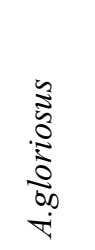 & 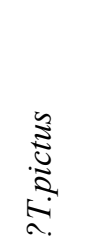 & 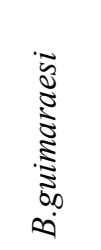 & 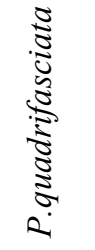 & 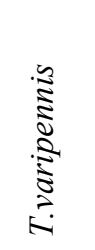 & 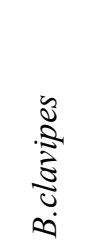 & 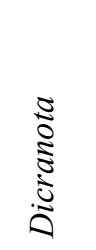 & 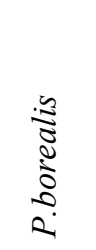 \\
\hline $\begin{array}{l}\text { Tanyderidae: } \\
\text { Protoplasa fitchii }\end{array}$ & 1.01 & 2.01 & 5.53 & 6.03 & 6.53 & 7.04 & 7.04 & 10.55 \\
\hline Araucoderus gloriosus & 0 & 1.01 & 5.03 & 5.53 & 5.53 & 6.03 & 6.03 & 10.55 \\
\hline ?Tanyderus pictus & 1.01 & 0 & 5.03 & 5.53 & 4.52 & 6.03 & 6.03 & 10.55 \\
\hline $\begin{array}{l}\text { Phlebotominae: } \\
\text { Brumptomiya guimaraesi }\end{array}$ & 5.03 & 5.03 & 0 & 4.52 & 4.52 & 6.53 & 6.53 & 11.06 \\
\hline $\begin{array}{l}\text { Ptychopterinae: } \\
\text { Ptychoptera quadrifasciata }\end{array}$ & 5.53 & 5.53 & 4.52 & 0 & 5.53 & 2.51 & 6.53 & 11.56 \\
\hline $\begin{array}{l}\text { Tipulidae: } \\
\text { Tipula varipennis }\end{array}$ & 5.53 & 4.52 & 4.52 & 5.53 & 0 & 5.53 & 5.03 & 11.56 \\
\hline $\begin{array}{l}\text { Bittacomorphinae: } \\
\text { Bittacomorpha clavipes }\end{array}$ & 6.03 & 6.03 & 6.53 & 2.51 & 5.53 & 0 & 5.53 & 11.06 \\
\hline $\begin{array}{l}\text { Pediciidae: } \\
\text { Dicranota } \text { sp. }\end{array}$ & 6.03 & 6.03 & 6.53 & 6.53 & 5.03 & 5.53 & 0 & 13.07 \\
\hline $\begin{array}{l}\text { Psychodinae: } \\
\text { Pneumia borealis }\end{array}$ & 10.55 & 10.55 & 11.06 & 11.56 & 11.56 & 11.06 & 13.07 & 0 \\
\hline
\end{tabular}

\section{COI gene sequences}

DNA sequencing is widely used to estimate genetic distances between animal populations. Based on 1333 mitochondrial COI sequences of 449 Diptera species, Meier et al. [2006] concluded that in true flies the divergence of nucleotide sequences is $0-7 \%$ between conspecific individuals, and $1-16 \%$ between congeneric species. In our analysis, partial COI sequences (Genbank accession numbers pending) were found to be identical between 2 Araucoderus gloriosus adults from the Lenca and Chanlefu Rivers (100 km apart), almost identical (single base pair difference $=0.16 \%$ nucleotide distance, $0 \%$ amino acid distance) between 2 ?Tanyderus pictus larvae from the Lenca River and NP Nahuelbuta (410 km apart), but markedly different between the adults and the larvae (15.18-15.34\% nucleotide distance, $1.89 \%$ amino acid distance). The estimated COI nucleotide divergence between ?T. pictus larvae and $A$. gloriosus was about the same as between ?T. pictus and Protoplasa fitchii, the only tanyderid previously sampled for COI [Beckenbach, 2012] (15.34 $15.49 \%$ ) and between A. gloriosus and Bittacomorpha clavipes $(15.48 \%)$ or Tipula varipennis $(15.49 \%)$. These data strongly indicated that the larvae did not belong to A. gloriosus. The amino acid divergence between ?T. pictus and $P$. fitchii was 2 times the divergence between each of them and $A$. gloriosus. The amino acid distances between these three tanyderids were much smaller than between them and some other nematocerans included in our comparison (Table).

\section{Larval habitats}

The larvae (Figs 3-5) were collected in Nothofagusdominated forests containing other broadleaved trees and some conifers (notably, Araucaria araucana in Nahuelbuta).

The first site, in Alerce Andino, was the forested fast-flowing Lenca River, at 340 masl, with a shingle bottom and abundant driftwood, usually almost whole dead Nothofagus trees, occasionally with preserved bark. The river in that area is of variable width, with occasional diagonal and mid-channel bars. At the exact place where the larvae were discovered the stream was about $10 \mathrm{~m}$ wide and had the maximum depth of about $1 \mathrm{~m}$. We first searched in vain in shallower places (up to $0.6 \mathrm{~m}$ deep) by stirring the bottom material up in front of 
a submerged collecting net and by examining submerged cobbles and logs with or without bark, but eventually found the larvae in two logs, 2-3 m long and approximately $15-20 \mathrm{~cm}$ in diameter pulled out from the fastflowing midstream, $0.5-1.0 \mathrm{~m}$ deep. A single larva in one $\log$ and numerous larvae of various instars in another were found under the bark. The bark, when pried with a knife, readily peeled off in large chunks and exposed wood of a peculiar light salmon colour (Fig. 4), with a strong, unpleasant smell, and with larvae crawling in a semiliquid pulp. The larvae were found in those portions of the logs where that substance was present. When disturbed, the larvae moved slowly and tried neither to hide nor to escape. Besides tanyderids, only numerous red larvae of Chironominae were found in these logs. No pupae were found despite a thorough search.

The second site, in Nahuelbuta $(410 \mathrm{~km}$ to the north from the first site), was a small forested creek at 1160 masl, with a sandy bottom, $0.1-0.2 \mathrm{~m}$ deep. One log, which yielded 2 larvae, was entirely submerged, possibly since recent heavy rains. Another log, where twenty larvae of various instars were concentrated, was slanting from the bank and had only its lower $1 / 3$ submerged into a dammed, almost stagnant part of the stream. The logs were about $15 \mathrm{~cm}$ thick and 1.5-2 $\mathrm{m}$ long. The first $\log$ had a characteristic smell, light salmon colour of wood, and its bark, when pried with a knife, readily peeled off in large chunks. The second log (probably a Nothofagus) had no such smell, its wood was light yellow-brown, and its bark peeled off with difficulty, in small chunks. Removal of the bark exposed small larvae crawling on the wood surface, and large ones residing in narrow chambers, often situated under a knot, within decomposing wood. The chambers were short, $3-5 \mathrm{~cm}$, straight, extending approximately subparallel to the surface. When disturbed, the larvae quickly retreated into the deeper parts of the chambers. Numerous larvae of other Diptera (Limoniidae, Pediciidae, Psychodidae, Chironomidae) and of Coleoptera were also found in

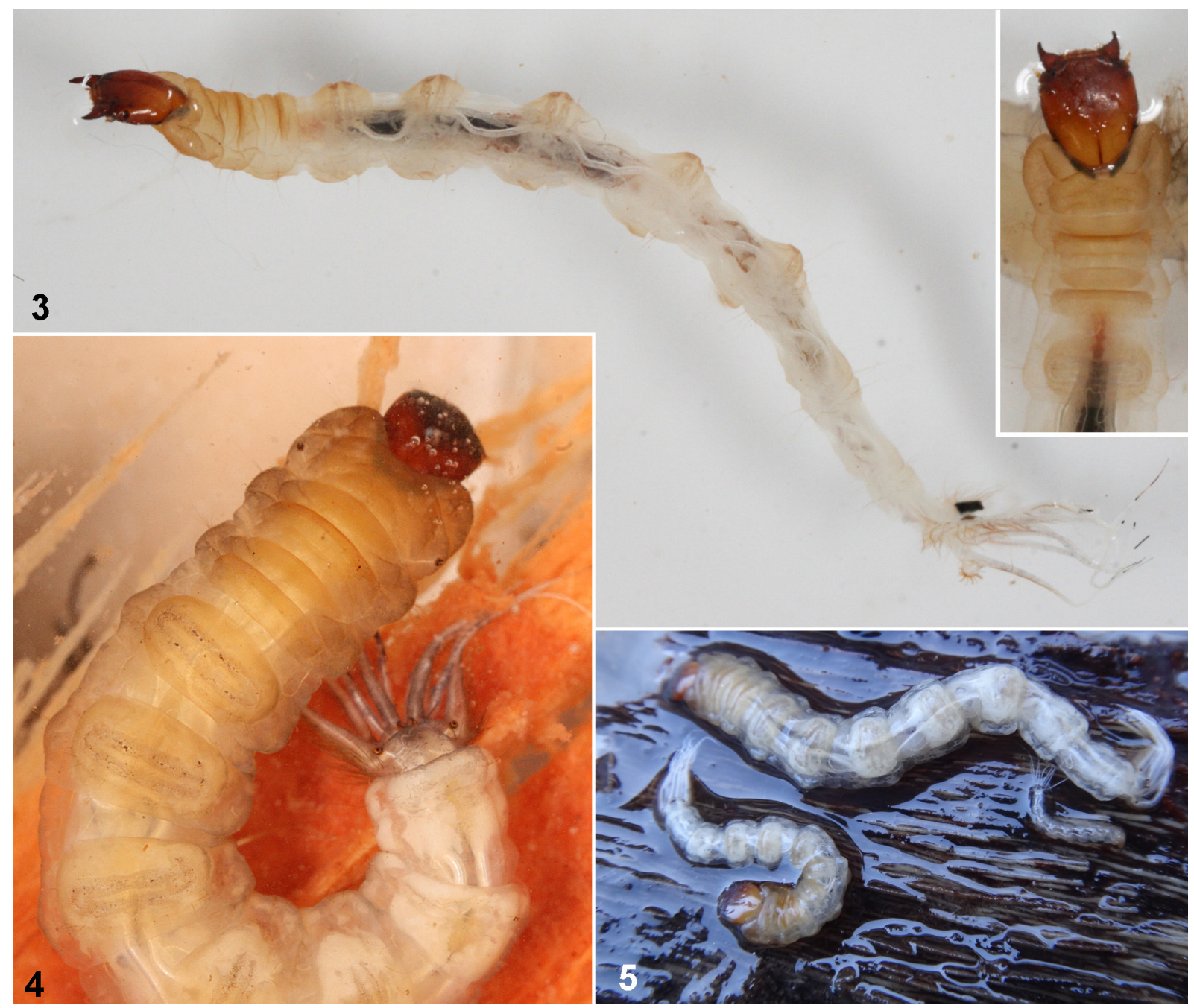

Figs 3-5. Live ?Tanyderus larvae: 3 - 3rd instar (inset: same specimen); $4-4$ th instar; $5-2$ nd, 3rd and 4th instars (3-4 Alerce Andino, photographs by R. Rakitov; 5 - Nahuelbuta).

Рис. 3-5. Живые личинки ?Tanyderus: 3 - III возраст (врезка, тот же экз.); 4 - IV возраст; 5 - II, III и IV возраст (3-4 - Алерсе Андино, фото Р. Ракитова; 5 - Науэльбута). 
these logs. In Nahuelbuta we found neither pupae nor adults of Tanyderidae.

Summarizing, we have collected tanyderid larvae in lotic habitats with different water velocities in Nothofagus-dominated forests, with trees growing close to the water. The larvae occurred under the bark of fallen dead tree trunks at the depths of $0.1-1.0 \mathrm{~m}$. The trunks were $15-20 \mathrm{~cm}$ in diameter and showed only initial stages of decomposition, their wood still light in colour and the bark remaining. Numerous smaller branches and numerous chunks of dead wood without bark were examined unsuccessfully.

\section{Morphology of larval instars}

The number of larval instars is four in most nematocerans [Hennig, 1948], but up to ten in some Simuliidae, Tabanidae and Asilidae [Crosskey, 1990; Esperk et al., 2007; Dennis et al., 2013]. For Tanyderidae the number of larval instars has never been reliably determined, but our material indicates that in Tanyderus it is most likely to be four. Based on the structure of spiracles and other body parts, as well as the size, we were able to distinguish in our material four larval instars, from the smallest larva with an egg-burster (doubtless the 1st instar) to very large, mature larvae. Distribution of head capsule width measurements showed no major gaps and, moreover, the size classes differed somewhat between the two collecting sites because the larvae from Alerce Andino were generally smaller. Twenty-two larvae were collected from Nahuelbuta, most of them probably being of the 2nd and 3rd instars, and only a few to the 4th instar. One larva, found in Nahuelbuts in the same log with numerous others, was distinctly smaller and remarkably different in structure; it is considered to be the 1st instar. Another 22 larvae were collected in Alerce Andino: three of the 3rd and the rest of the 4th instar.

The following characters of the 4th instar, common to all the known mature tanyderid larvae, including those previously described, appear to be of the family level and thus are not repeated below: Head essentially prognathous, somewhat flattened dorsoventrally, heavily sclerotized; its dorsal side extends posteriorly much farther (covered by prothoracic fold) than its ventral

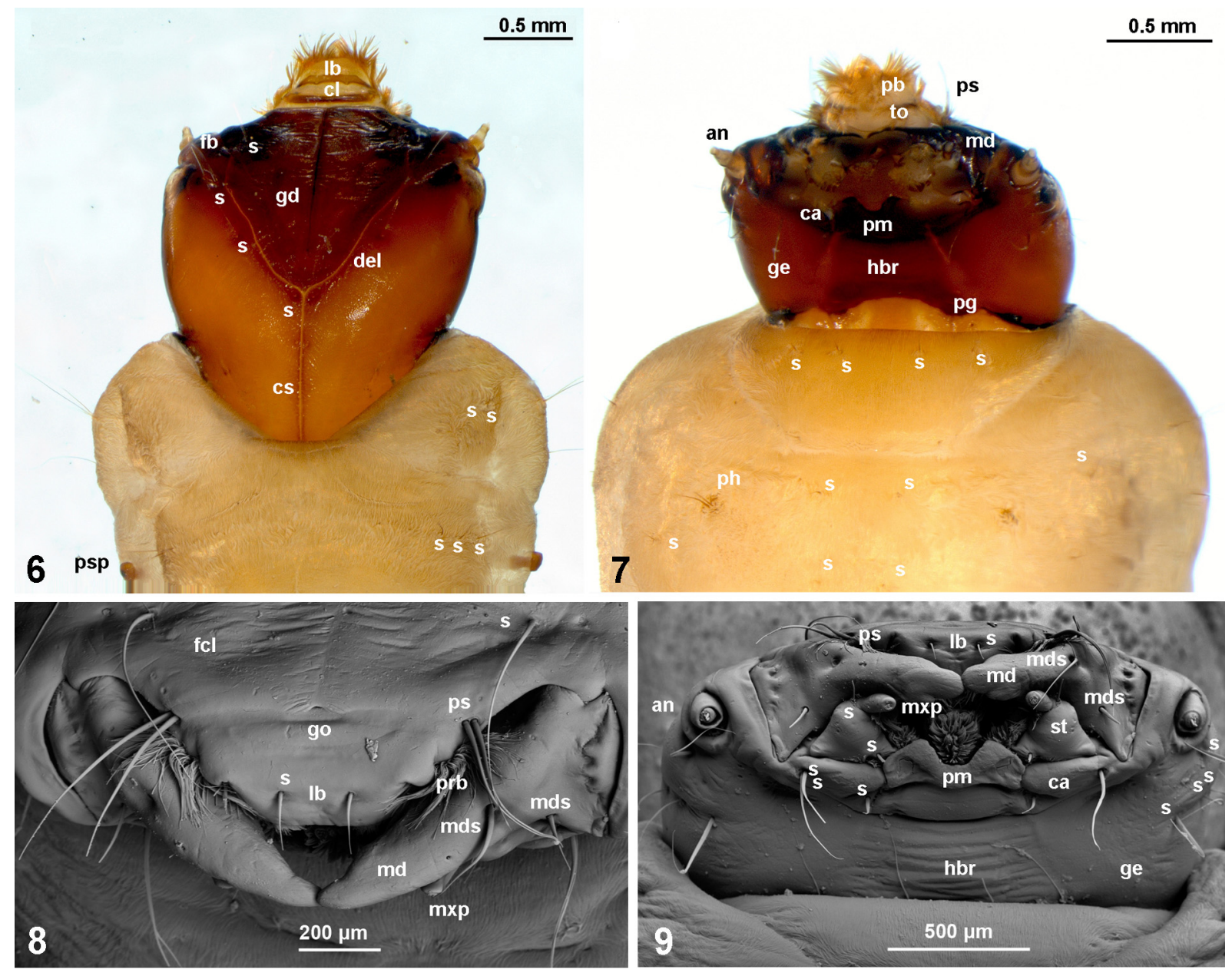

Figs 6-9. Head and thorax of 4th-instar ?Tanyderus larvae from Alerce Andino: 6 - dorsally; 7, 9 - ventrally; 8 - frontally $(8-9-$ SEM, BSE, gold-coated).

Рис. 6-9. Голова и грудь личинок ?Tanyderus IV возраста из Алерсе Андино: 6 - сверху; 7, 9 - снизу ; 8 - спереди (8-9 СЭМ, BSE, напылено золотом). 
side. Occipital foramen wide, oblique, its dorsal and lateral borders lined by strongly sclerotized and melanized postoccipital carina, with median interruption at origin of long coronal sulcus. Dorsal ecdysial lines diverging at sharp angles towards antennae. Antennae small, located anterolaterally in membranous aperture, partly surrounded by cuticular reinforcement branching off from peristomal ridge. Labrum membranous, with 2 conspicuous, dense palatal brushes of curved hairs. Mandibles massive, with 4 teeth and prosthecal brush. Abdominal segment VIII with 1 pair of filamentous tracheal gills; segment IX with 2 pairs of gills, ventral
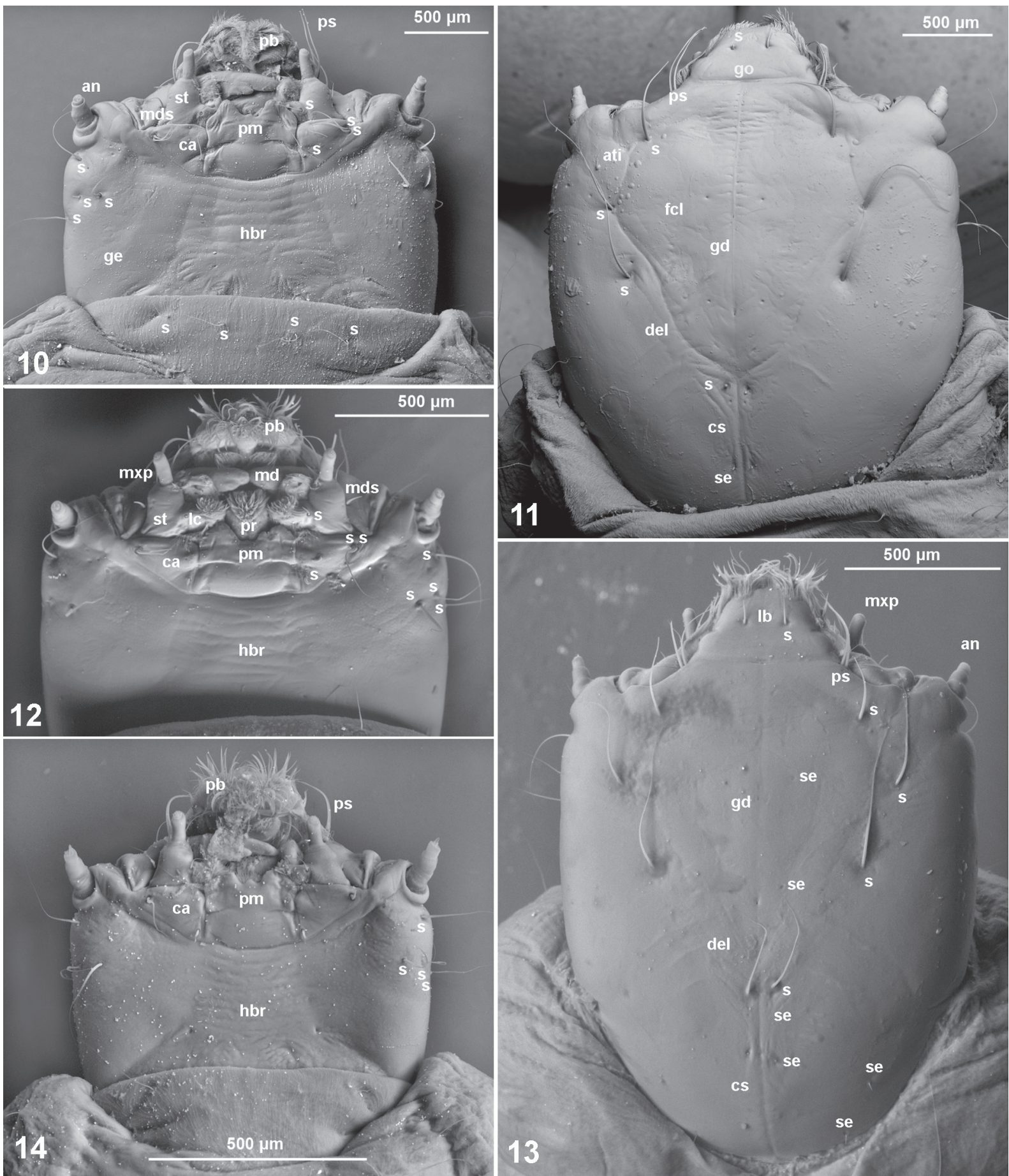

Figs 10-14. Head of ?Tanyderus larvae (SEM, BSE) from Nahuelbuta: 10-11 - 4th instar; 12-13 - 3rd instar; $14-2$ nd instar; 10, 12,14 - ventrally; 11,13 - dorsally (11 - gold-coated; $10,12-14$ - uncoated).

Рис. 10-14. Голова личинок? Tanyderus (СЭМ, BSE) из Науэльбуты: 10-11 — IV возраст; 12-13 — III возраст; 14 — II возраст; $10,12,14-$ снизу; 11,13 - сверху (11 - напылено золотом; $10,12-14$ - без напыления). 
pair bearing basally ambulatory pseudopods with 2 rows of curved hooks (shorter hooks in inner row; pseudopods low conical in Peringueyomyina), and with 2 pairs of anal papillae around anus.

4 d instar $(\mathrm{n}=23)$

Alerce Andino $(\mathrm{n}=19)$ : head length 1.60-2.27 (mean 1.94 ) $\mathrm{mm}$, width $1.37-2.02$ (mean 1.73 ) $\mathrm{mm}$, maximum total length of body $41 \mathrm{~mm}$ including $5.0 \mathrm{~mm}$ tail filaments; Nahuelbuta $(\mathrm{n}=4)$ : head length 2.37-2.75 (mean 2.58), width 2.0-2.50 (mean 2.23) mm, maximum total length of body 47 $\mathrm{mm}$ including $8.0 \mathrm{~mm}$ tail filaments.

Body (Figs 4-5, 23) dorsoventrally flattened; thoracic segments, especially prothorax, darker and more sclerotized, abdomen less sclerotized, moniliform, with distinct intersegmental constrictions in both live and fixed larvae. Head capsule and trunk segments each with stable pattern of several strong setae. Dorsal and ventral creeping welts distinct on abdominal segments $\mathrm{I}-\mathrm{V}$, but inconspicuous, appearing as fields of regularly arranged, modified seta-like microtrichia on mesothorax and metathorax. Integument of live specimens translucent, with 2 main longitudinal laterodorsal tracheal trunks and numerous short lateral muscles visible underneath; surface with long, recumbent hair-like microtrichia and intricate, deep, reticulate microsculpture.

Head (Figs 6-11). Eyes in anterolateral position just posterior to antenna. Areas of strongly melanized metacephalic sclerotization (posterior to melanized postoccipital carina) narrow, medially interrupted. Coronal sulcus long, extending for at least $1 / 3$ of head length; dorsal ecdysial line long, V-shaped, its branches converging anteriorly before level of antennae (turning point marked by seta), terminating in anterior tentorial invagination. Anterior margin of frontoclypeal apotome without lobes, straight. Narrow and strongly sclerotized and melanized glandular duct running medially beneath frontoclypeal apotome, opening as orifice at anterior margin of frons; medial surface of apotome with numerous nearly symmetrical transverse grooves ending on both sides of midline. Postmentum divided by incomplete transverse groove into two parts; anterior margin with deep notch separating 2 large teeth; postmentum, cardo and premaxillary ridge all heavily sclerotized and melanized; hypostomal bridge present, less melanized (as well as genae); small mesal portions of genae clearly separated, connected with middle part of hypostomal bridge and appearing as its projections. Postmentum, cardines, genae and hypostomal bridge separated by lines of weakness.

Antenna with 2 segments; basal segment larger, with only its proximal part sclerotized; distal segment retractile, with single small globular and at least 7 small and 2 large coneshaped sensilla. Insertion area of antenna oblique, anterolateral, covered by sclerotized knob. Labral and clypeal sclerites separate, bandlike, transverse; palatal brushes separated from small messors by sclerotized torma. Mandibles elongated, strongly sclerotized and melanized, pyramidal in shape; median tooth projecting much beyond other three, low-profile teeth. Maxilla complex, massive; cardo low triangular (wider than long); maxillary palp one-segmented with at least 12 apical sensilla, surrounded by rosette of sclerotized projections. Prementum apically with long dense microtrichia and short labial palpi bearing several sensilla.

Head chaetotaxy (Figs 6-11). At least 18 pairs of setae, mostly simple, $1-2$ setae near eye sometimes branched. Dorsally, 4 long strong setae along dorsal ecdysial line (1 seta
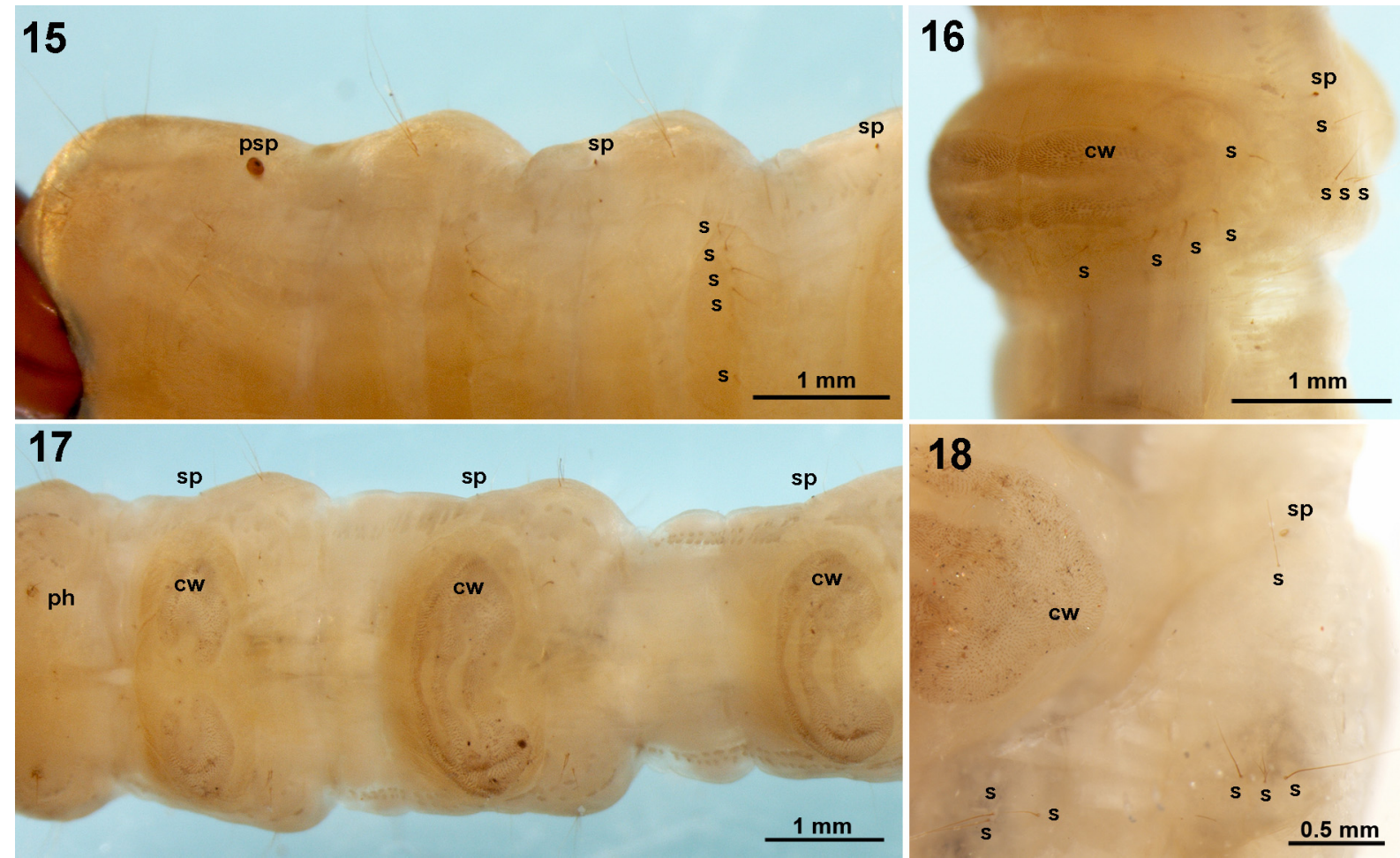

Figs 15-18. Body parts of 4th-instar ?Tanyderus larvae: 15-16 - dorsolaterally: 15 - thorax and segment I; 16 - segment I; 17 metathorax and segments I-III, ventrally; 18 - segment III, ventrolaterally.

Рис. 15-18. Детали строения личинки ?Tanyderus IV возраста: 15-16 — сверху-сбоку: 15 — грудь и сегмент I; 16 — сегмент I; 17 - заднегрудь и сегменты I-III, снизу; 18 - сегмент III, снизу-сбоку. 

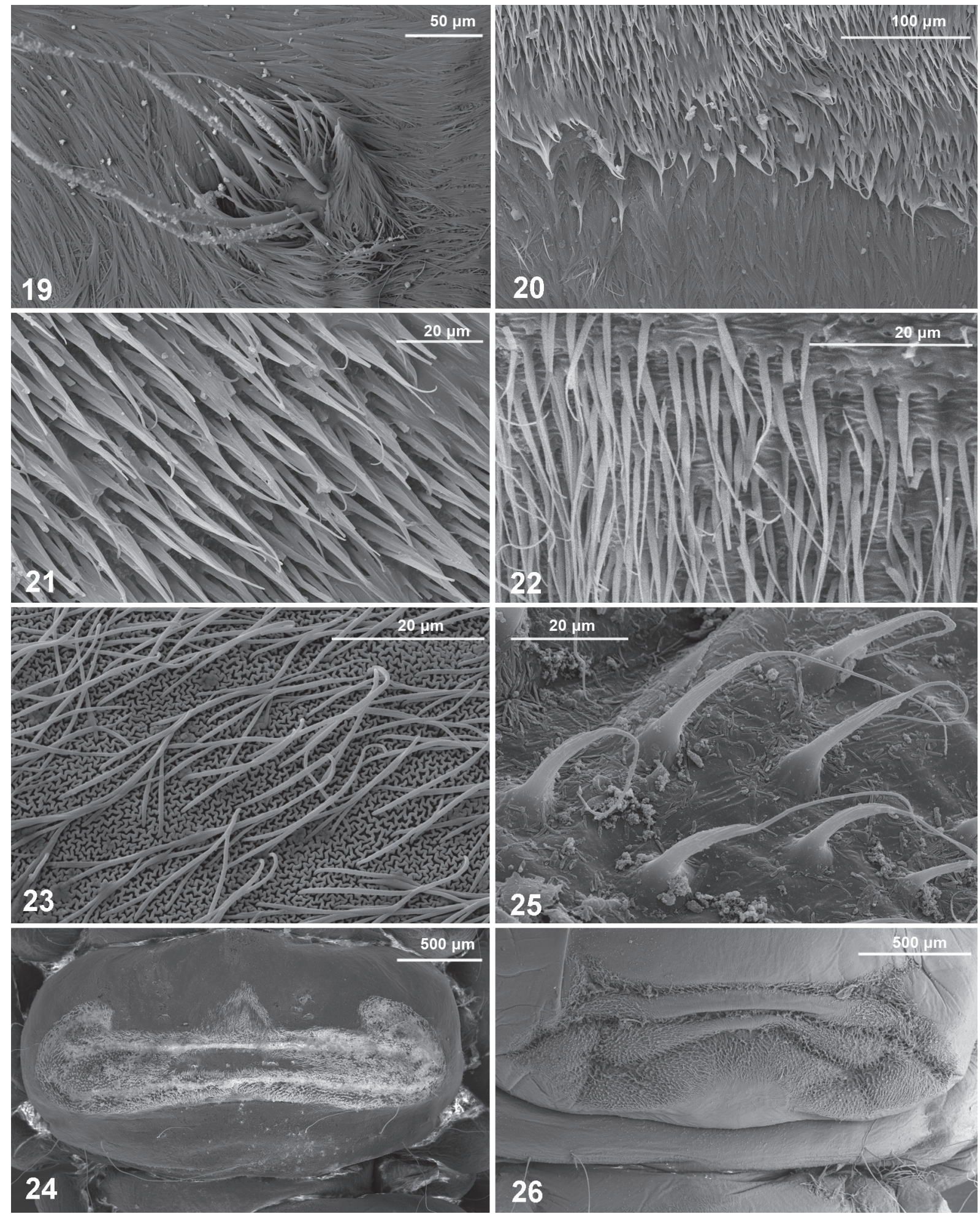

Figs 19-26. Details of ?Tanyderus larvae (SEM): 19 - podal hairs on mesothorax, 4th instar, ventrally; 20-22 - mesothoracic creeping welt, dorsally: 20 - margin of posterior zone, 4th instar; 21 - microtrichia of posterior zone, 4th instar; 22 - microtrichia of posterior zone, 2nd instar; 23 - microsculpture near dorsal creeping welt on segment IV, 4th instar; 24-26 - abdominal creeping welts: 24-25 - dorsally, 4th instar, segment III: 24 - total view; 25 - microtrichia; 26 - ventrally, 4th instar, segment IV, total view (19 - uncoated; 20-26 - coated; 20-21, 23-25 - SE; 19, 22 - BSE; 19-21, 25 - Alerce Andino; 22-24, 26 - Nahuelbuta).

Рис. 19-26. Детали строения личинок ?Tanyderus (СЭM): 19 - ножные щетинки на среднегруди, IV возраст, снизу; 20-22 ползательные валики на среднегруди, сверху: 20 - граница задней зоны, IV возраст; 21 - микротрихии задней зоны, IV возраст; 22 микротрихии задней зоны, II возраст; 23 - микроскульптура около спинного ползательного валика на сегменте IV, IV возраст; 24-26 ползательные валики на брюшке: 24-25 - сверху, IV возраст, сегмент III: 24 - общий вид; 25 - микротрихии; 26 — снизу, IV возраст, сегмент IV, общий вид (19- без напыления; 20-26 - напылено золотом; 20-21, 23-25 - SE; 19, 22 - BSE; 19-21, 25 - Алерсе Андино; 22-24, 26 - Науэльбута) 


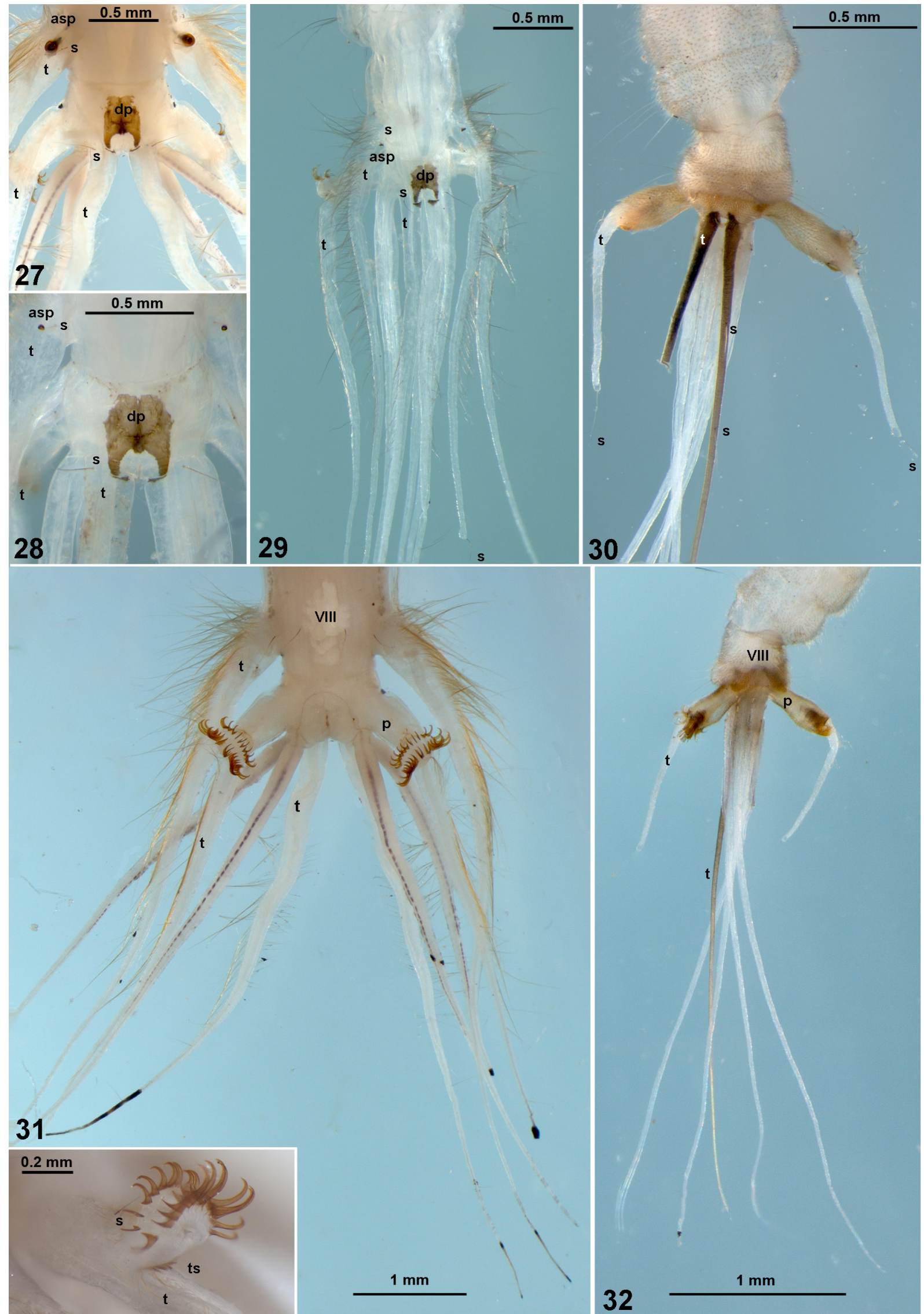



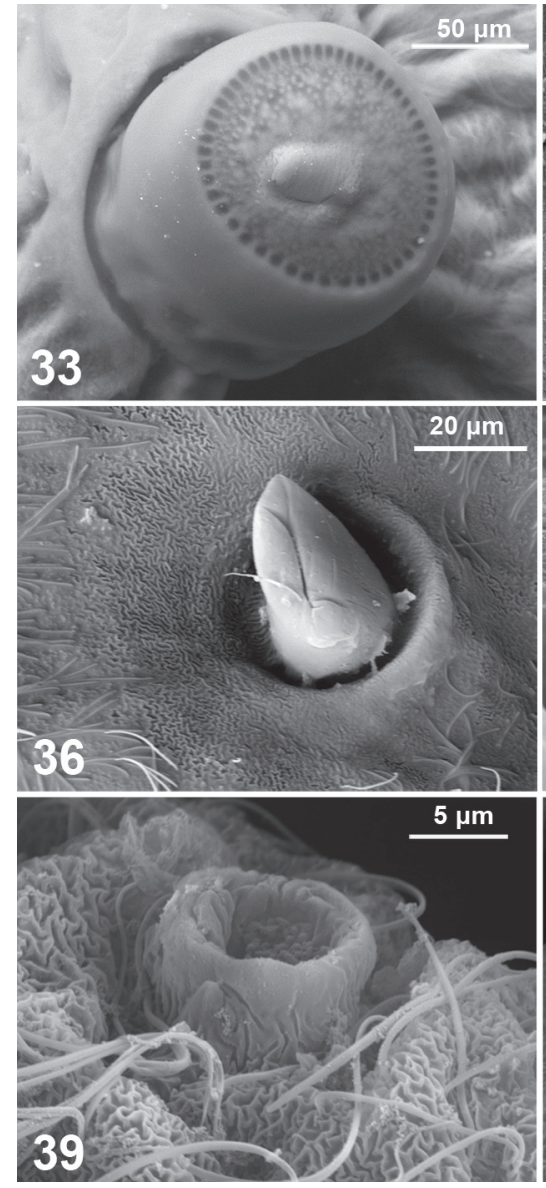
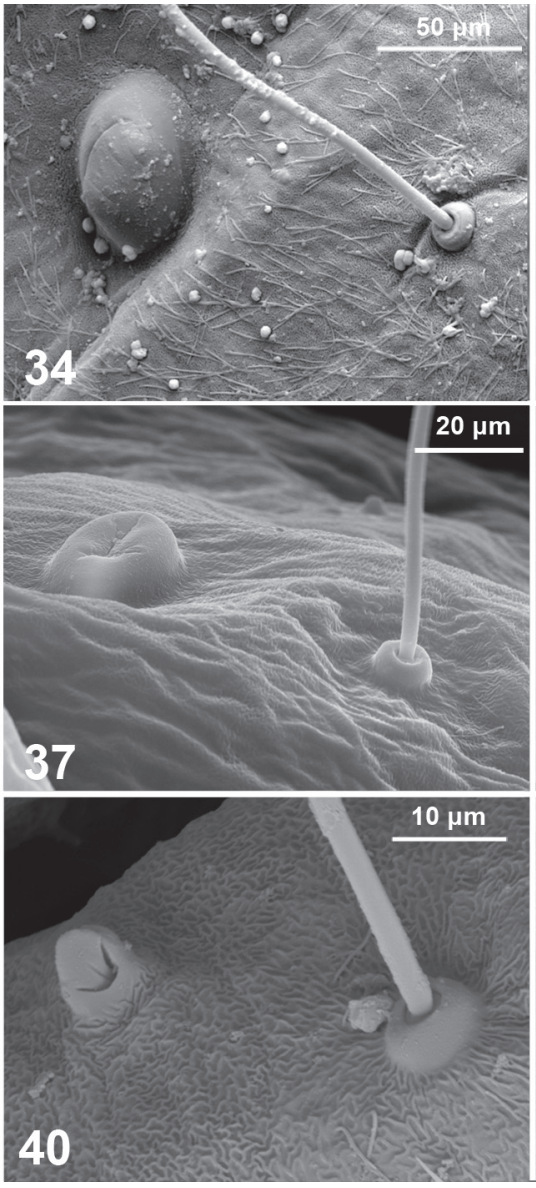
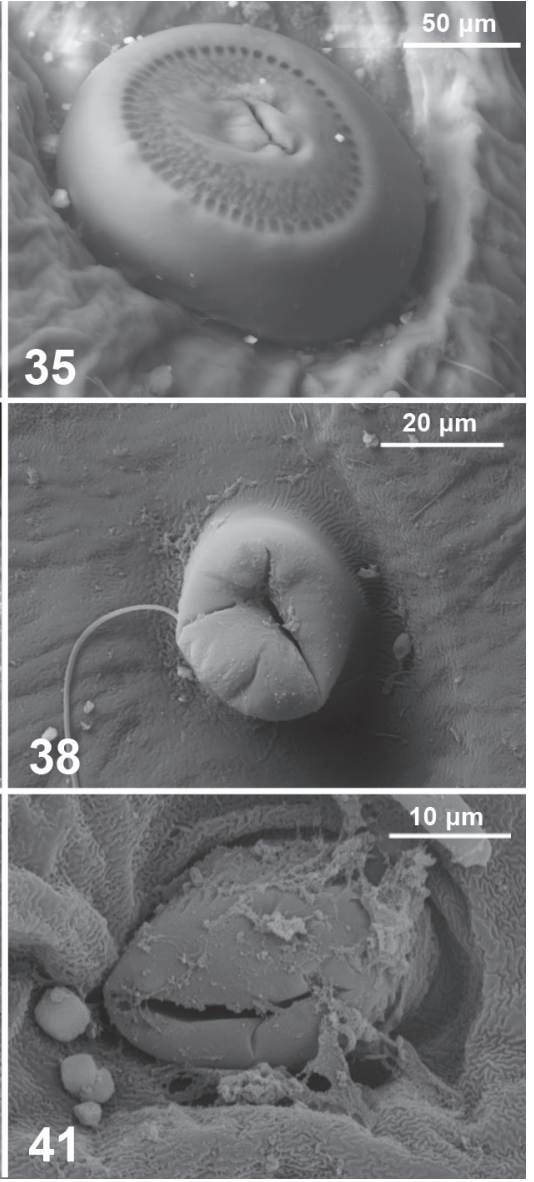

Figs 33-41. Spiracles of ?Tanyderus larvae (SEM): 33-35 - 4th instar: 33 — prothoracic; 34 - on segment VII; 35 - postabdominal; 36-38 - 3rd instar: 36 - prothoracic; 37 - on segment VII; 38 - postabdominal; 39-41 - 2nd instar: 39 - prothoracic; 40 - on segment V; 41 - postabdominal (33, 35 - uncoated; 32, 34, 36-41 - coated; 33, 35-36, 38-41 - BSE; 34, 37 - SE; 33, 35 - Alerce Andino; 34, 36-41 - Nahuelbuta).

Рис. 33-41. Дыхальца личинок ?Tanyderus (CЭM): 33-35 - IV возраст: 33 - переднегрудное; 34 — на сегменте VII; 35 — заднее; 36-38 - III возраст: 36 — переднегрудное; 37 — на сегменте VII; 38 - заднее; 39-41 - II возраст: 39 — переднегрудное; 40 — на сегменте V; 41 - заднее (33, 35 - без напыления; 32, 34, 36-41 - напыление золотом; 33, 35-36, 38-41 - BSE; 34, 37 - SE; 33, 35 - Алерсе Андино; 34, 36-41 - Науэльбута).

near end of coronal sulcus and another marking its turning point), 2 long strong close-set paraclypeal setae, and 1 shortest labral seta. Laterally, 1 medium-sized seta posterior to antennal socket at anterior eye margin, and 3 setae in oblique row posterior to eye (upper and/or middle seta sometimes branched, with up to 4 branches). On cardo, 1 posteromesal and 2 close-set anterolateral setae; basal part of mandible and stipes of maxilla each with 2 setae. At least 6 pairs of sensilla visible on dorsal surface: 4 along midline (2 campaniform along glandular duct and 2 trichoid along coronal sulcus) and 2 trichoid posterolaterally.

Thorax (Figs 4, 15-16, 20-21). Prothorax longer than remaining thoracic segments. Each thoracic segment subdivided by constriction into 2 annuli. Mesothorax and metathorax each bearing inconspicuous, flat creeping welts representing slightly darker areas with semierect to adpressed, sometimes flattened, parallel seta-like microtrichia arranged in transverse groups or rows; dorsal welt consisting of anterior and posterior zones, ventral welt of anterior zone only.

Thoracic chaetotaxy (Figs 6-7, 15-16, 19). On each side of prothorax: dorsally, 1 anterolateral pair of setae (outer seta sometimes branched), 1 longitudinal pair of setae near midline, and posterior row of 3 setae before spiracle level; laterally, 4 anterior setae; ventrally, 2 setae just behind head, small bare spot with 4 close-set podal hairs (2 long and 2 short), 1 longitudinal pair of setae near midline, and 1 longitudinal pair ventrolaterally. On each side of mesothorax and metathorax: dorsally, 1 anterolateral pair of trichoid sensilla, row of 5 seta at hind margin of posterior zone of creeping welt

Figs 27-32. End of abdomen of ? Tanyderus larvae, 27-30 — dorsally: 27 - 4th instar; 28 - 3rd instar; 29 - 2nd instar; 30 - 1st instar; 31-32 - ventrally: 31 - 4th instar (inset, pseudopod with hooks and tuft of setae, another specimen); 32 - 1st instar (27, 31 - Alerce Andino; 28-30, 32 - Nahuelbuta).

Рис. 27-32. Конец брюшка личинок ?Tanyderus, 27-30 — сверху: 27 - IV возраст; 28 - III возраст; 29 — II возраст; 30 — I возраст; 31-32 - снизу: 31 - IV возраст (врезка, ложноножка с крючками и пучком щетинок, другой экз.); 32 - I возраст (27, 31 - Алерсе Андино; 28-30, 32 - Науэльбута). 
(inner one set apart from the rest, outer one sometimes branched); laterally, row of 4 setae (behind spiracle on metathorax; usually one of inner setae branched); ventrally, 2 trichoid sensilla in anterior row, bare spot with 4 close-set podal hairs ( 2 long and 2 short), 1 longitudinal pair near midline, and 1 longitudinal pair ventrolaterally. Pairs of contralateral setae sometimes with one seta branched and another simple.

Abdomen (Figs 17, 24-27, 31). Creeping welts on segments $\mathrm{I}-\mathrm{V}$ convex, transversely oval to bean-shaped (emarginate posteriorly), covered with variously thickened, curved spinules (modified microtrichia) with flagelliform apices, except for 2 spineless transverse bands, in dorsal welts anterior band open anteriorly (anterior welt margin forming 2 lateral projections); each ventral welt situated more anteriorly than its dorsal counterpart; first ventral welt divided medially. All 5 pairs of tail filaments (gills and papillae) long, subequal in length, with gills slightly longer. Tracheal gills with powerful tracheal trunk, long hairs (much longer than gill diameter, most dense on first pair of segment VIII gills), and few long, spaced dorsal setae, including terminal one. Ambulatory pseudopods with 11-15 short hooks in inner and 12-16 long hooks in outer row (number of hooks in outer row usually exceeding that in inner row by 1-2 hooks; number of hooks sometimes different between left and right pseudopod); base of pseudopod with tuft of setae posteriorly; segment IX with median dorsal sclerotized plate, inverted U-shaped, and with small accessory sclerites at gill bases.

Abdominal chaetotaxy (Figs 18, 27, 31). On each side of segments I-VII: dorsally, 1 anterolateral trichoid sensillum ( 2 on segment I), 1 pair of setae posterior to it (inner seta at

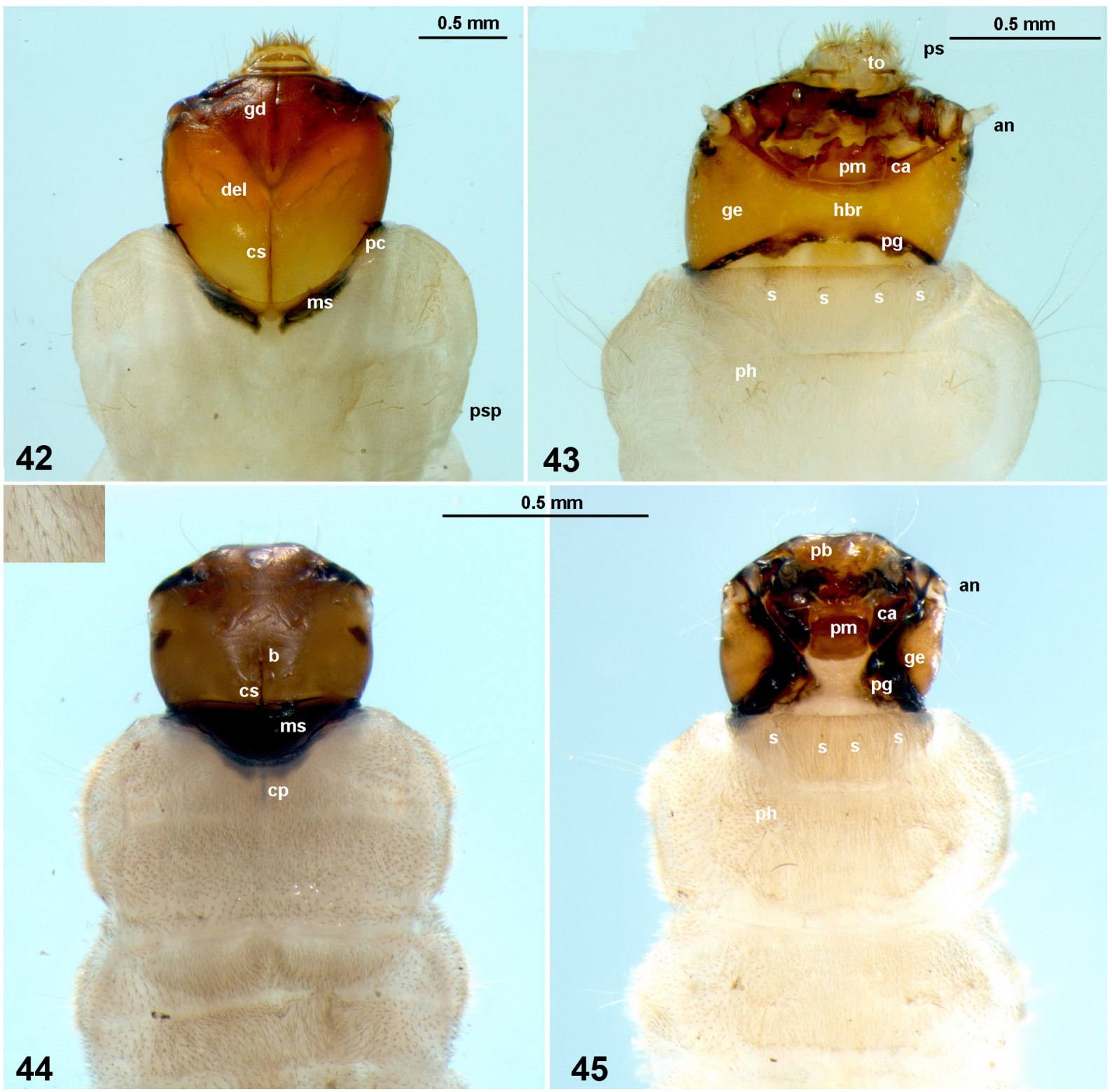

Figs 42-45. Head and thorax of ?Tanyderus larvae from Nahuelbuta: $42-3$ rd instar, dorsally; $43-2$ nd instar, ventrally; $44-45-$ 1st instar; 44 - dorsally; 45 - ventrally (inset, setation of prothorax).

Рис. 42-45. Голова и грудь личинок ?Tanyderus из Науэльбуты: 42 - III возраст, сверху; 43 — II возраст, снизу; 44-45 — I возраст; 44 - сверху; 45 - снизу (врезка, опушение переднегруди, тот же экз.) 
anterior emargination of dorsal welt on segments $\mathrm{I}-\mathrm{V}$, outer seta branched into up to 10 branches), row of 4 setae behind dorsal welt (inner one set apart from the rest); laterally, 1 seta behind spiracle and 3 setae in posterior row (middle one branched); ventrally, 1 oblique to longitudinal anterior pair of trichoid sensilla, 1 pair of short setae (on segments I-V within ventral welt, outer seta lateral to posterior spineless band, inner seta near posteromedian emargination on segments II-V and anterior to outer seta on segment I), and posterior row of 3 setae ( 2 inner setae close-set). On each side of segment VIII dorsally, 1 anterior trichoid sensillum, 1 seta median of spiracle; ventrally, 1 longitudinal pair of trichoid sensilla, 2 setae in posterior row. On each side of segment IX: dorsally, 1 seta at base of gill behind dorsal sclerotized plate; ventrally, 1 seta at pseudopod base.

Respiratory system (Figs 15, 27, 33-35) with 10 pairs of spiracles: large prothoracic and postabdominal (at bases of tracheal gills on segment VIII) spiracles and small but dis-

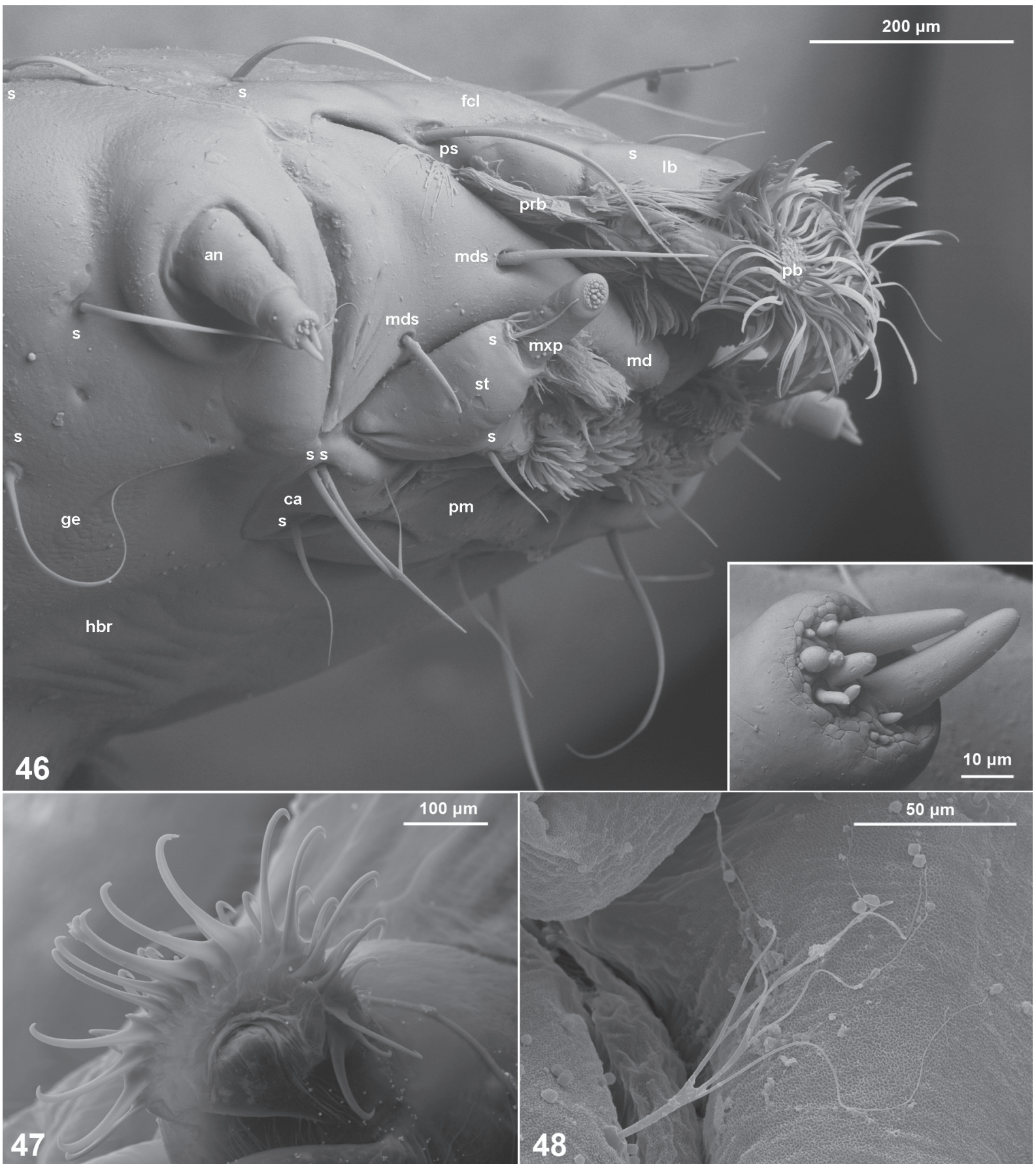

Figs 46-48. Body parts of ?Tanyderus larva from Nahuelbuta (SEM, coated): 46-47 — 3rd instar: 46 — head, laterally (inset, apex of antenna); 47 - pseudopod with hooks; 48 - 2nd instar (46-47 - BSE; $48-\mathrm{SE})$.

Рис. 46-48. Детали строения личинок ?Tanyderus из Науэльбуты (СЭМ, напылено золотом): 46-47 — III возраст: 46 — голова, сбоку (врезка, вершина антенны, тот же экз.); 47 - ложноножка с крючками; 48 - II возраст (46-47 - BSE; 48 - SE). 
tinctly sclerotized rudimentary spiracles on metathorax and abdominal segments I-VII (before lateral setae); prothoracic and postabdominal spiracles each with spiracular plate bearing circle of numerous minute pores at periphery and internal reticulate structure; all spiracles with central ecdysial scar.

$3 r d$ instar $(\mathrm{n}=11)$

Alerce Andino ( $\mathrm{n}=3)$ : head length 1.15-1.52 (mean 1.35) $\mathrm{mm}$, width $1.0-1.27$ (mean 1.13) $\mathrm{mm}$; Nahuelbuta $(\mathrm{n}=8)$ : head length $1.45-1.75$ (mean 1.59) mm, width $1.12-1.50$ (mean 1.30) $\mathrm{mm}$.

Similar to 4th instar (Figs 3, 5, 12-13, 42, 46-47), but respiratory system (Figs 28,36-38) with small prothoracic and postabdominal spiracles without visible pores, only with central ecdysial opening, and even smaller, sclerotized, protruding spiracles on metathorax and abdominal segments IVII; eyes sometimes in more posterior position (beneath or posterior to row of 3 setae).

2nd instar ( $\mathrm{n}=9$, Nahuelbuta)

Head length $0.97-1.15$ (mean 1.06) mm, width 0.77 0.95 (mean 0.89) $\mathrm{mm}$.

Similar to 3rd instar (Figs 5, 14, 22, 43, 48), but postmentum with small median tooth between 2 large lateral teeth, respiratory system (Figs 29, 39-41) with small, sclerotized postabdominal spiracles and even smaller, protruding, nonsclerotized spiracles on prothorax, metathorax and abdominal segments I-VII, without visible pores; metathoracic and abdominal spiracles I-VII subequal in diameter to setal bases, prothoracic ones only slightly larger; eyes sometimes in more posterodorsal position (visible from above, posterior to row of 3 setae).

1st instar ( $\mathrm{n}=1$, Nahuelbuta).

Head length $0.55 \mathrm{~mm}$, width $0.52 \mathrm{~mm}$; total length of the body $11.3 \mathrm{~mm}$ including $3.4 \mathrm{~mm}$ tail filaments.

Differs markedly from 2nd-4th instars. Body not flattened, its sides almost parallel; each segment with few long simple setae and uniform cover of short seta-like threebranched microtrichia (Fig. 44, inset); creeping welts on abdominal segments I-V rudimentary, only on ventral side, appearing as blisters with rows of short spinules, encircled by glabrous oval; segments VI and VII longest.

Head (Figs 44-45) with eyes in dorsolateral position (visible from above, posterior to row of 3 setae), extensive triangular area of heavily melanized metacephalic sclerotization and sclerotized inner margins of genae and cardines. Coronal sulcus short (1/4 head length), visible on metacephalic sclerotized area and beyond it as black stripe of coronal phragma; dorsal ecdysial lines absent. Anterior margin of frontoclypeal apotome without lobes, straight. Depressed area with melanized spot on midline of frontoclypeal apotome (probably rudiment of glandular duct); glandular duct not visible. Egg-burster as tiny bordered melanized spot on anterior end of coronal sulcus. Bipartite postmentum as rectangular plate with serrated anterior margin, less sclerotized than inner margins of cardines and genae; hypostomal bridge absent; mesal portions of genae separated from each other and postmentum by broad membranous area.

Labrum membranous, with 2 lateral palatal brushes of curved hairs. Mandibles elongated, strongly sclerotized and melanized. Maxilla complex, massive; cardo elongate triangular (longer than wide).

Head chaetotaxy (Figs 44-45) similar to that of mature larva, with 17 pairs of simple setae (compared to mature larvae, with only 1 seta not visible at each side, on mandible, due to position of the latter): dorsally, 4 long strong setae (situated as in mature larvae, 1 seta near end of coronal sulcus), 2 long strong close-set paraclypeal setae, and 1 shortest labral seta; laterally, 4 setae posterior to antennal socket. Cardo with 1 posteromesal and 2 close-set anterolateral setae; basal part of mandible with 1 seta visible; stipes of maxilla with 2 setae.

Thoracic segments (Figs 44-45) subdivided, without distinct creeping welts on either side, dorsally with group of simple setae anterolaterally on prothorax, and ventrally with 2 pairs of podal hairs on each segment.

Abdomen (Figs 30, 32). Segment VIII without filaments. Segment IX with 4 pairs of filaments: 1 dorsal pair of long dark tracheal gills, each with few long spaced dorsal setae, including terminal one; 2 slightly longer pairs of anal papillae; and 1 ventral pair of much shorter gills (1/3 length of dorsal pair), each with terminal seta. Pseudopods with curved hooks, hard to count due to retracted condition, but at least with 10 in each row; base of pseudopod uniformly pubescent, without tuft of setae on posterior margin; sclerotized dorsal plate on segment IX absent. Respiratory system apneustic, without visible spiracles.

REMARKS. Similar to all Southern Hemisphere genera with known larvae (and different from both Northern Hemisphere genera) in the following characters: to Mischoderus in the presence of the glandular duct and long, dense hairs on the gills, to Radinoderus in one of the seta near eye being usually branched, dorsal plate present on segment IX, tuft of setae at the pseudopod base, and anal papillae being subequal to the gills, to Eutanyderus in the abdomen with distinct constrictions and creeping welts on thoracic and abdominal segments, to all above genera in the presence of the hypostomal bridge (see photo of Eutanyderus [Hawking et al., 2014]), and to Peringueyomyina in the antenna with 2 large cone-shaped sensilla (fide Wood [1952]; only 1 large sensillum is indicated for that genus by Exner \& Craig [1976]). Distinct from all above genera in combination of these characters. Presence of 8 pairs of rudimentary spiracles is recorded in larvae of Tanyderidae for the first time.

\section{Key to gENERA of TANYderidAe (MATURE LARVAE)}

1 Tracheal gills shorter than abdomen width, anal papillae even shorter; pseudopods low conical .......................... Peringueyomyina Alexander, 1921

- Tracheal gills and anal papillae longer; pseudopods cylindrical.

2 Hypostomal bridge present; anterior margin of frontoclypeal apotome straight ................................................ 3

- Hypostomal bridge absent; anterior margin of frontoclypeal apotome emarginate

3 Segment IX with dorsal sclerotized plate; anal papillae subequal to gills; base of pseudopod posteriorly with tuft of setae

- Segment IX without dorsal sclerotized plate; anal papillae shorter than gills; base of pseudopod posteriorly without tuft of setae (unknown for Eutanyderus) .................... 5

4 Head with glandular duct; creeping welts present; gills with long, dense hairs (longer than gill diameter) ... ?Tanyderus Philippi, 1865

- Head without glandular duct; creeping welts absent; gills without long hairs ........ Radinoderus Handlirsch, 1909

5 Head with glandular duct; creeping welts absent; gills with long, dense hairs .......... Mischoderus Handlirsch, 1909

- Head without glandular duct; creeping welts present; gills without long, dense hairs Eutanyderus Alexander, 1928

6 Anal papillae shorter than pseudopods Protanyderus Handlirsch, 1909

- Anal papillae not shorter than pseudopods ..................... Protoplasa Osten-Sacken, 1860 


\section{Discussion}

Larval feeding. Feeding by larvae was not observed, but their mandibles swing mostly in the horizontal plane (as in Protanyderus and Mischoderus [Exner \& Craig, 1976; Anthon, 1988]), can be protracted until their tips point directly forwards (Fig. 3), and are additionally used in substrate locomotion. The gut contents were studied in 2 larvae (2nd and 4th instars) from Nahuelbuta. In the older larva the gut seemed to contain only wood fragments, but in the younger one it additionally contained some fungal hyphae; in both larvae fragments of xylem were identified (Figs 49-52). The characteristics of the wood elements, primarily intervessel scalariform to opposite bordered pits suggest wood of one of the forest dominants, Nothofagus (A. Broushkin, pers. comm.). These tanyderid larvae are wood gougers making their own chambers in Nothofagus driftwood, rather than occupying cavities made by other invertebrates. So, the statement that some tanyderid larvae are "gougers or shredders given their habit of boring into rotting logs" [Hawking et al., 2014] is applicable to ?Tanyderus as well. However, the larvae found in Alerce Andino lived without chambers, even the last instar crawling under the bark in a smelly semiliquid pulp. Although our attempt to study their gut contents has failed, we can suppose that they scrape algae, bacteria and diatoms. Therefore, ?Tanyderus larvae appear to have opportunistic feeding habits.

Life cycle. Based on the simultaneous presence in Nahuelbuta of all 4 larval instars in the same log we suggest a semivoltine, 2-year life cycle for that population. Such cycles are known in some other wood-inhabiting flies, e.g. Axymyiidae [Krogstad, 1959]. However, the predominance of mature larvae and absence of the first two instars rather suggests a univoltine cycle for the population in Alerce Andino. The difference can be due to better nutrition (the semiliquid substance these larvae were found in appears more nutritious), as well as the warmer climate at the Alerce Andino site, where snow cover is not formed during winter, in contrast to the Nahuelbuta site. It is worth mentioning that the mature larvae from Alerce Andino are clearly smaller than those from Nahuelbuta and thus can be expected to produce smaller adults. Recently, for Axymyia furcata McAtee it has been suggested that the smaller individuals had an opportunity "to move more quickly through its development and to pupate in a single year," so that sympatric univoltine and semivoltine lineages may exist [Wihlm \& Courtney, 2011]. Although insufficient to confirm this hypothesis, our material does not contradict it.

Larval morphology and changes between instars. In his comprehensive study of Mischoderus larvae Anthon [1988] discovered several remarkable characters not found among other nematocerans. The first one is a narrow, strongly sclerotized glandular duct running medially beneath the frontoclypeal apotome. Anthon suggested it to be unlikely "that such a remarkable morphological feature should only be found in Mischoderus." Therefore, although this structure has been reported as absent in the recently studied larvae of Protanyderus, Protoplasa and Radinoderus [Judd, 2004; Podeniene \& Gelhaus, 2013], its discovery in ?Tanyderus larvae comes as no great surprise. Wipfler et al. [2012] found in Protanyderus sp. a mediodorsal endocarina corresponding in its position to the glandular duct of Mischoderus, and suggested it, without further discussion, to be an autapomorphy of Tanyderidae. It is possible that the mediodorsal endocarina is also present in Protoplasa and Radinoderus, but in these genera it is pale and not visible externally. In ?Tanyderus the glandular duct appears to be absent or rudimentary during the 1 st instar. On heads of the 3 rd and 4 th instars (Figs $6,8,11)$ one can see, in addition to the glandular duct with its anterior orifice, 2 external pits just above the duct, marking its midlength and end, and some 20 transverse grooves at both sides of the duct, each termi-
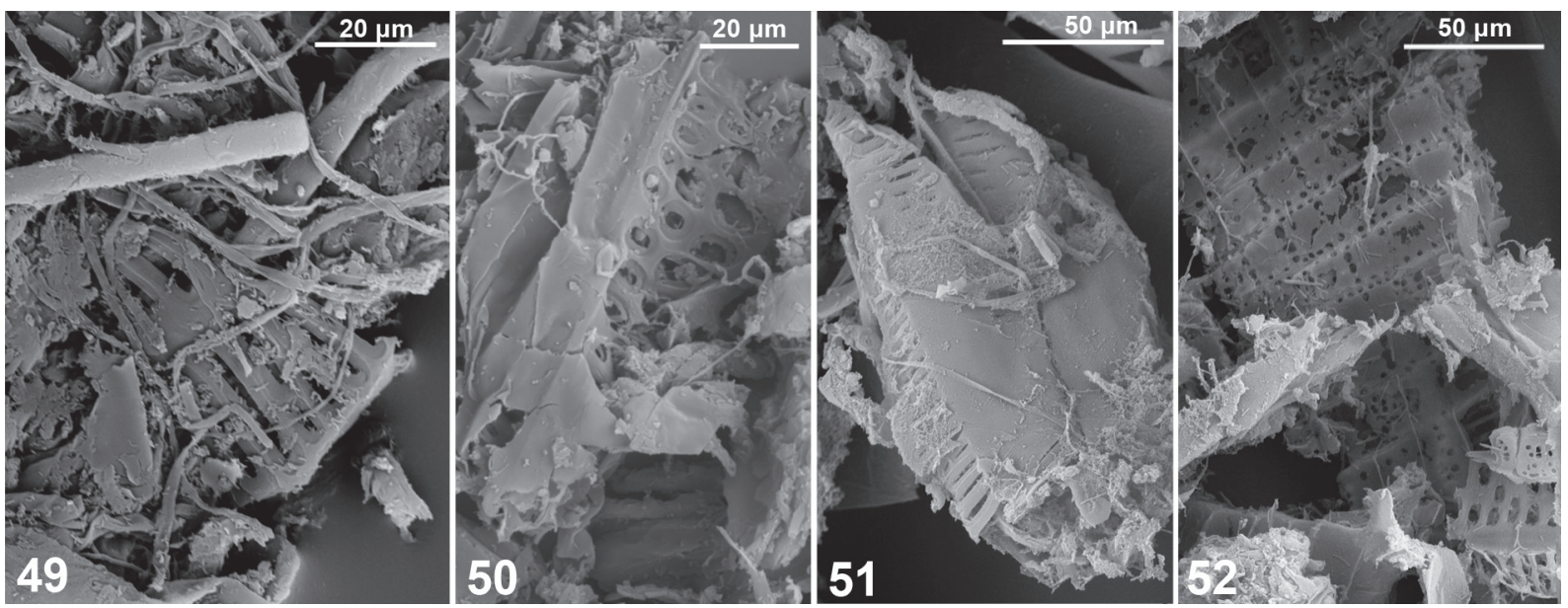

Figs 49-52. Wood fragments among gut contents of ? Tanyderus larvae (SEM, coated, BSE; Nahuelbuta): 49-50 — 2nd instar, note fungal hyphae; 51-52 - 4th instar.

Рис. 49-52. Фрагменты древесины в содержимом кишечника личинок ?Tanyderus (СЭМ, напылено золотом, BSE; Науэльбута): 49-50 - II возраст, видны грибные гифы; 51-52 — IV возраст. 
nating in a pit just before the midline, so that the glandular duct appears lined at both sides with nearly symmetrically arranged pits. The function of the presumed gland remains unknown. The larvae of Mischoderus, the only other genus with the glandular duct recorded, have been collected from the bed of a stream containing scattered woody debris, and successfully reared feeding on decaying twigs [Pilgrim, 1990]. It is logical to suppose that the presence of the duct correlates with xylophagy. Yet, no such glandular duct is visible on photos of the head capsule of Eutanyderus larvae, boring in surface layers of submerged rotting logs [Hawking et al., 2014].

Another unusual feature described by Anthon [1988] in Mischoderus is the difference between the last and the penultimate larval instars, first of all in the configuration of the posterior part of their head capsules. Although recorded in just one genus, it has been considered to be an autapomorphy of the family [Wipfler et al., 2012]. However, nothing similar was found by us in ?Tanyderus: most 4th-instar characters, except the spiracle pattern and number of teeth on the postmentum, are present already in the 2 nd instar. The greatest difference is found between the 1 st and 2 nd instars. Furthermore, in ?Tanyderus, the metacephalic sclerotization is best developed in the 1st instar (Fig. 44), whereas in Mischoderus it is exaggerated in the 3rd and diminished in the 4th instar.

An early instar larva of Mischoderus from New Zealand has briefly been commented on as having only 2 slender tail filaments, in contrast to a cluster of tail filaments in the late instars [Moore, 2014]. We suppose it to be the 1st-instar larva, possessing 1 dorsal pair of long tracheal gills, the other gill pair (with pseudopods) being probably very short and the first pair (on segment VIII) absent like in ?Tanyderus. Therefore, such transformation of the gill pattern, the appearance of an additional gill pair on the segment VIII in the 2 nd instar, is now recorded in two tanyderid genera.

In the 1 st instar of ?Tanyderus the hypostomal bridge is not yet formed, in contrast to all subsequent larval instars (Figs 7, 10, 12, 14, 43, 45); the genae, cardines and postmentum are separated by a broad membranous area, and it is evident that the 2 triangular sclerites lateral to this area are mesal portions of the genae, in agreement with Anthon [1988], not derivatives of the labium as supposed by Crampton [1930]; in later instars these sclerites adjoin the bridge. Formation of the hypostomal bridge during larval ontogeny may parallel evolutionary transformations of this area in Tanyderidae and related groups. The hypostomal bridge is absent in Protoplasa and Protanyderus, but is present in Mischoderus, Radinoderus [Anthon, 1988; Judd, 2009] and Eutanyderus [Hawking et al., 2014] and is characteristic of Psychodidae. When discussing the relationships of Tanyderidae and Psychodidae, Wipfler et al. [2012] erroneously opposed these families based on the absence/presence of the hypostomal bridge. We have found an additional similarity between these families: subdivision of the thoracic seg- ments into 2 annuli occurs in both ?Tanyderus larvae and some Psychodidae.

The 1st-instar larva was not studied by SEM, as we decided that it should best be preserved in a wet state, but it clearly had no spiracles visible in a light microscope (Fig. 30), suggesting the apneustic respiratory system. The 2 nd instar has a single pair of small sclerotized spiracles on abdominal segment VIII (Fig. 29), and therefore appears metapneustic. However, after careful examination we additionally found 1 pair of smaller, non-sclerotized prothoracic and 8 pairs of even smaller, non-sclerotized spiracles on the metathorax and abdominal segments I-VII (Figs 39-41), bringing the total number of spiracle pairs developed in the 2 nd instar to 10 . Those rudimentary spiracles are easy to find due to their association with the chaetotaxy: they are situated anterodorsal to the anteriormost lateral seta, on the abdominal segments I-VII, or to the lateral transverse row of 4 setae, on the metathorax. Using SEM we have found that these rudimentary spiracles protrude above the surface and bear a central opening or slit. In the 3rd instar all the spiracles become larger, the prothoracic ones become sclerotized and subequal in size to the postabdominal ones, these 2 pairs being larger than the rest, and no spiracle showing any visible pores (Figs 36-38). In the 4rd instar all the spiracles become larger once again, especially the prothoracic and postabdominal ones, both of these pairs being the only spiracles that acquire at this stage spiracular plates, each bearing a strongly sclerotized central portion with the ecdysial scar and outer circle of minute pores (Figs 27, 33-35). Hence, using the terminology of Keilin [1944], only in the last instar the prothoracic and postabdominal spiracles of the type I become transformed into the type II, in which the ecdysial opening is obliterated. Keilin described in detail the complex internal structure of the postabdominal spiracle of the tipulid Ctenophora, consisting of chitinous rods and lacunae. Similar microstructures, recorded in many dipteran families in the atrium of both prothoracic and postabdominal spiracles, have been interpreted as a plastron, ensuring breathing both in the water and in the air [Krivosheina, 2005]. In ?Tanyderus the internal plastron reticulations are visible through the spiracular plate on SEM images of uncoated larvae, taken at high voltage $(30 \mathrm{kV})$ with a BSE detector (Figs 33, 35).

The described changes in the respiratory system may indicate that in the course of development the larva progressively changes from apneustic (1st instar, no spiracles), to metapneustic (2nd instar, postabdominal spiracles begin to function), to amphipneustic (3rd instar, functional prothoracic spiracles are added), and finally to holopneustic (4th instar, previously rudimentary eight pairs of spiracles become functional). However, it seems much more likely that the 4th-instar larva is actually amphipneustic, with only its prothoracic and postabdominal spiracles functional and the 8 other pairs non-functional, consistently with their small size and the absence of visible pores. A similar situation is known e.g. in apneustic larvae of Simuliidae, which 
have the prothoracic and 8 pairs of abdominal spiracles developed as tiny dark scars, none of them functional [Crosskey, 1990]. An increase in the number of spiracles during the course of larval development and simultaneous presence of different spiracle types are common in Diptera, but the youngest stage is usually metapneustic, while the holopneustic condition is rarely attained and has been previously recorded only in a few families with terrestrial larvae (Bibionidae, Hesperinidae, Pachyneuridae [Keilin, 1944; Krivosheina \& Mamajev, 1967]).

Some such configurations have already been recorded in Tanyderidae: a condition similar to the 2nd-instar ?Tanyderus (prothoracic spiracles invisible; postabdominal ones small, probably non-functional) in the supposed 2nd-instar Protanyderus [Exner \& Craig, 1976], and a condition similar to the 3rd-instar ?Tanyderus (prothoracic and postabdominal spiracles rudimentary, subequal, probably non-functional) in Mischoderus [Anthon, 1988]. Yet, this is the first record of an apneustic 1 st instar and of 8 pairs of rudimentary spiracles in the 2nd, 3rd and 4th instars in Tanyderidae.

Additionally we examined a mature larva of Palearctic Protanyderus sp. (the specimen illustrated by Krivosheina [2012: photo 78]), which turned out to have the same pattern of lateral abdominal chaetotaxy as in ?Tanyderus (Figs 16, 18): each segment bearing a simple anterior seta plus a transverse row of 3 setae (middle one branched) posterior to it. The metathorax and segments I-VII bear rudimentary spiracles, certainly non-functional, neither sclerotized nor protruding, situated anterodorsally to the anterior seta, and visible as small bare spots with pale midline among elsewhere uniform pubescence.

Developing under the bark of deeply submerged logs larvae of ?Tanyderus usually have no access to the atmospheric air. Anthon [1988] suggested that spiracles would be of little importance for underwater respiration, this function being taken over by tracheal gills and, possibly, the entire body surface. We can add that the combination of highly dissected, reticulate microsculpture with dense microtrichia on the integument of ?Tanyderus larvae (Figs 23,48) may function as a plastron [Marx \& Messner, 2012]. These structures may also provide protection against abrasion damage, as has been suggested by Exner \& Craig [1976] for the complex microsculpture of Protanyderus larvae.

ACKNOWLEDGEMENTS. We are deeply indebted to Mario Elgueta (National Museum of Natural History, Santiago) and the CONAF staff of the Alerce Andino, Nahuelbuta and Puyehue national parks for facilitating our field work in Chile. We heartily thank Roman Rakitov (Borissiak Paleontological Institute RAS, Moscow) for helping us take scanning electron images, editing the draft manuscript, and other assistance in various areas of the study, Nikolai Mugue (Russian Federal Research Institute for Fisheries and Oceanography, Moscow) for sequencing the COI gene and helping us interpret the molecular data, Natalia Gordenko and Anatoly Broushkin (Borissiak Paleontological Institute RAS,
Moscow) for helping identify the gut contents, Ruben Isai Madriz (Iowa State University, Ames) for information about other records of Tanyderidae from Chile, Mikhail Chertoprud (Moscow State University) for loaning us a Protanyderus larva, and Marina Krivosheina, Nina Krivosheina (Severtsov Institute for Ecology and Evolution RAS, Moscow) and Vladimir Blagoderov (Natural History Museum, London) for helpful comments.

The research was partly supported by the Russian Foundation for Basic Research, project no. 13-04-01839.

\begin{tabular}{ll}
\multicolumn{2}{c}{ Abbreviations used in the figures } \\
an & antenna \\
asp & postabdominal spiracle \\
ati & anterior tentorial invagination \\
b & egg burster \\
ca & cardo \\
cl & clypeal sclerite \\
cp & coronal phragma \\
cs & coronal sulcus \\
cw & creeping welt \\
del & dorsal ecdysial line \\
dp & dorsal plate \\
fcl & frontoclypeal apotome \\
gd & glandular duct \\
ge & gena \\
go & glandular orifice \\
hbr & hypostomal bridge \\
lb & labral sclerite \\
lc & lacinia \\
md & mandible \\
mds & mandibular seta \\
ms & metacephalic sclerotization \\
mxp & maxillary palp \\
p & pseudopod \\
pb & palatal brush \\
pc & postoccipital carina \\
pg & mesal projection of gena \\
ph & podal hairs \\
pm & postmentum \\
pr & prementum \\
prb & prosthecal brush \\
ps & paraclypeal seta \\
psp & prothoracic spiracle \\
s & seta \\
se & sensilla \\
sp & rudimentary spiracle \\
st & stipes \\
t & tracheal gill \\
to & torma \\
ts & tuft of setae \\
&
\end{tabular}

\section{References}

Alexander C.P. 1913. A revision of the South American dipterous insects of the family Ptychopteridae // Proceedings of the United States National Museum. Vol.44. P.331-335.

Alexander C.P. 1920. A new genus and species of net-winged midge (Blepharoceridae) and an undescribed species of Tanyderidae (Diptera) // Arkiv för Zoologi. Vol.13. No.7. P.1-7.

Alexander C.P. 1928. The Australasian species of the genus Nemopalpus (Psychodidae, Diptera) // Proceedings of the Linnean Society of New South Wales. Vol.53. P.291-294.

Alexander C.P. 1929. Diptera of Patagonia and South Chile. Part I. Crane-flies (Tipulidae, Trichoceridae, Tanyderidae). London: British Museum (Natural History). 240 p. 
Alexander C.P. 1930. Observation of the dipterous family Tanyderidae // Proceedings of the Linnean Society of New South Wales. Vol.55. P.221-232.

Alexander C.P. 1936. The distribution of Tanyderus pictus Ph. (Fam. Tanyderidae, Ord. Diptera) // Revista Chilena de Historia Natural. Vol.39. P.86-87.

Alexander C.P. 1952. New or little-known Tipuloidea (Diptera) from Argentina. Part I //Acta Zoologica Lilloana. Vol.10. P.75-94.

Alexander C.P. 1959. Undescribed species of nematocerous Diptera Part VII // Bulletin of the Brooklyn Entomological Society. Vol.54. P.53-59.

Alexander C.P. \& Alexander M.M. 1967. Family Tanyderidae // Catatalogue of the Diptera of the Americas South of the United States. Vol.5. P.5.1-5.3.

Ansorge J. 1994. Tanyderidae and Psychodidae (Insecta: Diptera) from the Lower Jurassic of northeastern Germany // Paläontologische Zeitschrift. Vol.68. P.199-209.

Anthon H. 1988. Larval morphology of Mischoderus (Insecta, Diptera, Nematocera, Tanyderidae) with notes on tanyderid affinities // Zoologica Scripta. Vol.17. P.381-394.

Beckenbach A.T. 2012. Mitochondrial genome sequences of Nematocera (lower Diptera): evidence of rearrangement following a complete genome duplication in a winter crane fly // Genome Biology and Evolution. Vol.4. P.89-101.

Colless D.H. \& McAlpine D.K. 1970. Chapter 34. Diptera // Waterhouse D.F. (ed.). Insects of Australia. Melbourne University Press, Carlton, Victoria, P.656-740.

Crampton G.C. 1930. A comparison of the more important structural details of the larva of the archaic tanyderid dipteron Protoplasa fitchii with other Holometabola from the standpoint of phylogeny // Bulletin of the Brooklyn Entomological Society. Vol.25. P.239-258.

Crosskey R.W. 1990. The Natural History of Blackflies. New York: John Wiley \& Sons. 712 p.

Curler G.R. \& Moulton J.K. 2012. Phylogeny of psychodid subfamilies (Diptera: Psychodidae) inferred from nuclear DNA sequences with a review of morphological evidence for relationships // Systematic Entomology. Vol.37. P.603-616.

Dennis D.S., Barnes J.K. \& Knutson L. 2013. Review and analysis of information on the biology and morphology of immature stages of robber flies (Diptera: Asilidae) // Zootaxa. Vol.3673. P.1-64.

Esperk T., Tammaru T. \& Nylin S. 2007. Intraspecific variability in number of larval instars in insects // Journal of Economic Entomology. Vol.100. P.627-645.

Exner K. \& Craig D.A. 1976. Larvae of Alberta Tanyderidae (Diptera: Nematocera) // Quaestiones Entomologicae. Vol.12. P.219-237.

Folmer O., Black M., Hoeh W., Lutz R. \& Vrijenhoek R. 1994. DNA primers for amplification of mitochondrial cytochrome c oxidase subunit I from diverse metazoan invertebrates // Molecular Marine Biology and Biotechnology. Vol.3. P.294-299.

Hawking J.H, Smith L.M. \& LeBusque K. 2014. Identification and ecology of Australian freshwater invertebrates: Tanyderidae http://www.mdfrc.org.au/bugguide/view.asp http:// www.mdfrc.org.au/bugguide/view.asp?PhotoID=6212 http:// www.mdfrc.org.au/bugguide/view.asp?PhotoID $=6664$

Hennig W. 1948. Die Larvenformen der Dipteren. Vol. 1. Berlin: Akademie-Verlag. 185 p.

Judd D.D. 2004. Insecta: Diptera, Tanyderidae // Yule C.M., Yong H.S. (eds). Freshwater Invertebrates of the Malaysian Region. Academy of Sciences Malaysia, Kuala Lumpur. P.626-633.

Kalugina N.S. 1992. Psychodomorph dipterans from the Jurassic of Mongolia (Diptera: Tanyderidae, Eoptychopteridae) // Palaeontologicheskiy Zhurnal. No.3. P.110-113.

Keilin D. 1944. Respiratory system and respiratory adaptations in larvae and pupae of Diptera // Parasitology. Vol.36. P.1-66.

King P.P. 1832. Sailing Directions for the Coasts of Eastern and Western Patagonia... London: Hydrographical Office, Admiralty. viii $+155 \mathrm{p}$.

Knight A.W. 1963. Description of the tanyderid larva Protanyderus margarita Alexander from Colorado // Bulletin of Brooklyn Entomological Society. Vol.58. P.99-102.
Krivosheina M.G. 2005. The plastron is a universal structure that ensures breathing of dipteran larvae both in the water and in the air // Doklady Biological Sciences. Vol.401. P.112-115.

Krivosheina M.G. 2012. Keys to the Palaearctic families and genera of nematocerous larvae (Diptera, Nematocera). Moscow: KMK Scientific Press. 244 p.

Krivosheina N.P. \& Mamajev B.M. 1967. New data on the families Hesperinidae and Pachyneuridae and their position in the order Diptera // Zoologicheskiy Zhurnal. Vol.46. P.235-247 [in Russian].

Krogstad B.O. 1959. Some aspects of the ecology of Axymyia furcata McAtee (Diptera: Sylvicolidae) // Proceedings of the Minnesota Academy of Sciences. Vol.27. P.175-177.

Krzemiński W. \& Judd D.D. 1997. Family Tanyderidae // Papp L., Darvas B. (eds). Contributions to a Manual of Palaearctic Diptera (with special reference to flies of economic importance). Vol.2. Nematocera and Lower Brachycera. Science Herald, Budapest. P.281-289.

Krzemiński W., Azar D. \& Skibińska K. 2013. Nannotanyderus ansorgei $\mathrm{sp} . \mathrm{n}$., the first member of the family Tanyderidae from Lebanese amber (Lower Cretaceous) // Azar D., Engel M., Jarzembowski E., Krogmann L., Santiago-Blay J. (eds). Insect Evolution in an Amberiferous and Stone Alphabet. Proceedings of the 6th International Congress on Fossil Insects, Arthropods and Amber, Brill, Leiden. P.131-143.

Lukashevich E.D. \& Krzemiński W. 2009. New Jurassic Tanyderidae (Diptera) from Asia with first find of larvae // Zoosymposia. Vol.3. P.155-172.

Marx M.T. \& Messner B. 2012. A general definition of the term "plastron" in terrestrial and aquatic arthropods // Organisms Diversity and Evolution. Vol.12. P.403-408.

Meier R., Shiyang K., Vaidya G. \& Ng P.K. 2006. DNA barcoding and taxonomy in Diptera: a tale of high intraspecific variability and low identification success // Systematic Biology. Vol.55. P.715-728.

Moore S. 2014. Freshwater invertebrates guide: primitive cranefly (Tanyderidae: Mischoderus) http://www.landcareresearch.co.nz/ resources/identification/animals/freshwater-invertebrates/guide/ no-jointed-legs $2 /$ true-fly-larvae/other/primitive-cranefly

Pilgrim R.L.C. 1990. A role of amateurs in New Zealand entomology // New Zealand Entomologist. Vol.13. P.1-6.

Podeniene V. \& Gelhaus J.K. 2013. Larva of Protanyderus stackelbergi Savchenko, 1971 (Diptera: Ptychopteromorpha, Tanyderidae) from Mongolia // Proceedings of the Academy of Natural Sciences of Philadelphia. Vol.162. P.125-132.

Poinar G.O.Jr., Brown A.E. 2006. The enigmatic Dacochile microsoma Poinar \& Brown: Tanyderidae or Bruchomyiinae? // Zootaxa. Vol.1162. P.19-31.

Rose J.H. 1963. Supposed larva of Protanyderus vipio (Osten Sacken) discovered in California // The Pan-Pacific Entomologist. Vol.39. P.272-275.

Wiegmann B.M., Trautwein M.D., Winkler I.S., Barr N.B, Kim J.W., Lambkin C., Bertone M.A., Cassel B.K., Bayless K.M., Heimberg A.M., Wheeler B.M., Peterson K.J., Pape T., Sinclair B.J., Skevington J.H., Blagoderov V., Caravas J., Kutty S.N., Schmidt-Ott U., Kampmeier G.E., Thompson F.C., Grimaldi D.A., Beckenbach A.T., Courtney G.W., Friedrich M., Meier R. \& Yeates D.K. 2011. Episodic radiation in the fly tree of life // Proceedings of the National Academy of Sciences. Vol.108. P.5690-5695.

Wihlm M.W. \& Courtney G.W. 2011. The distribution and life history of Axymyia furcata McAtee (Diptera: Axymyiidae), a wood inhabiting, semi-aquatic fly // Proceedings of the Entomological Society of Washington. Vol.113. P.385-398.

Wipfler B., Courtney G.W., Craig D.A. \& Beutel R.G. 2012. First ìCT-based 3D reconstruction of a dipteran larva - the head morphology of Protanyderus (Tanyderidae) and its phylogenetic implications // Journal of Morphology. Vol.273. P.968-980.

Wood H.G. 1952. The crane-flies of the South-West Cape (Diptera, Tipuloidea) // Annals of the South African Museum. Vol.39. P.1-327. 